\title{
Las bibliotecas del otoño medieval. Con especial referencia a las de Castilla en el siglo XV
}

\author{
ANTONIO ANTELo IGLESIAS *
}

A Inés

\section{LOS PRELUDIOS LAICOS}

En una sociedad de cultura mayoritariamente audiovisual como lo fue, para el Occidente latino-germánico desde sus inicios, la que solemos designar con el término de «medieval», tuvo, sin embargo, notoria influencia la palabra escrita o, en sentido amplio, el “libro" ${ }^{1}$. Junto con la tradición oral, se comprueba asimismo tal ascendiente del Libro en otras

* Profesor Emérito de Historia Medieval, UNED. El tema fue desarrollado el 18 de julio de 1990, con ocasión de la «I Semana de Estudios sobre la Corona de Castilla. Siglo XV». Curso de Verano de la UNED, Ávila (16-20 julio).

1 La aplicación, al Occidente medieval, de los métodos científicos que han arrojado tanta luz sobre otras sociedades, permite hoy contemplar ese pasado europeo como una civilización en la que el oido y la vista fueron dominantes. "La Edad Media de los últimos descubrimientos - afirma Le Goff, J._... no es la Edad Media de las partes nobles revelada por la historiografía tradicional, de la que surgió La Leyenda Dorada de la época medieval. Es una Edad Media de las profundidades, de los fundamentos, de las estructuras... Ciertamente, no se trata de olvidar que la Edad Media, o más bien una pequeña élite medieval, sabía también leer, pero esta Edad Media esencial se halla más próxima a la verdad de una época en la que la enorme mayoría -illiteratus, «iletrado", con un sentido más o menos amplio..., equivalía a laico, noble o campesino- era analfabeta" (cf. La civilisation de l'Occident médiéval, Paris 1964, pág. 17). A su vez, Curtius, E. R., pone de relieve la valoración del libro como símbolo: véase Literatura europea y Edad Media latina, trad. espñ., vol. I. México 1955, págs. 423-489. 
civilizaciones del Viejo Mundo, como las orientales, configuradas a su vez por el decisivo factor religioso; pero la Cristiandad —en cuyo seno cobró forma Europa - avanzaría desde una perspectiva sacral, que abarca totalitariamente su historia hasta el fecundo siglo XII, hacia nuevos horizontes de relativa secularización. Así, pues, el libro - por tanto, las bibliotecas-, evolucionaría también al compás de esa trayectoria ${ }^{2}$. Los estudiosos han propuesto distinguir, en consecuencia, dos fases: 1. ${ }^{2}$ ) la "monástica», durante la cual el poder eclesiástico ejerce su magisterio sobre las generaciones altomedievales, dentro del jerárquico estatismo feudal; y $2^{\text {a) }}$ la que, no sin reservas, podemos considerar ya «laíca», o de tendencias profanas, desde el siglo XIII hasta el $\mathrm{XV}^{3}$. A la primera corresponde el códice primorosamente elaborado y adscrito, en principio, al medio conventual ad maiorem Dei gloriam; mientras que, a la segunda, vincúlase el libro concebido y realizado para un tipo de lector explicable por las transformaciones económico-sociales del Bajo Medioevo, que darán paso al «intelectual» en los círculos universitarios y al burgués comprometido, por sus actividades comerciales, bancarias e industriales, con el precapitalismo ya ascendente. No es, claro está, una división tajante que marque un "antes" y un "después", con netos perfiles diferenciales: las mutaciones históricas no hacentabla rasa del pasado, sino que éste, en virtud de la inercia social y de la que $F$. Braudel ha denominado «larga duración», actúa en el presente ${ }^{4}$. "Los scriptoria, organizados se-

${ }^{2}$ Acerca del Libro en las sociedades organizadas sacralmente, véase GARCíA PELAYO, M., "Las culturas del Libro", en Los mitos políticos. Madrid 1981, págs. $352-390$ (especialmente, 355-372). Este ágil y notable ensayo apareció en la Revista de Occidente (Madrid), Nos. 24 y 25, marzo y abril, 1965. Es asimismo importante la posición de MARAvall, J. A., ante los problemas que la traditio oral y escrita plantea para la Edad Media: véase "La concepción del saber en una sociedad tradicional", en Estudios de historia del pensamiento español, Serie primera: Edad Media. 2. ${ }^{a}$ ed. ampliada. Madrid 1973, págs. 215-271. - Sobre las bibliotecas medievales, en general, véase: CAvalLo, G., ed., Libri e lettori nel Medioevo. Guida storica e critica. Roma 1977. CHRIST, K., Handbook of Medieval Library History. Engl. transl. Londres, 1984. Escolar, H., Historia de las bibliotecas. Madrid 1985. Etudes sur le vocabulaire intellectuel du Moyen Âge, vol. II: Vocabulaire du livre et de l'écriture au Moyen Âge, Turnhout, Bélgica 1989 (Actes de la Table Ronde, Paris, 24-26 sept. 1987), sobre todo págs. 136-154. J. DE GHELLINCK, S. J., "Les bibliothèques médiévales", en Nouvelle Revue Théologique, LXV (1939), 36-55. Millares CaRLo, A., Introducción a la historia del libro y de las bibliotecas. México 1975, págs. 61-62 y 251-263. Puede aún consultarse útilmente la erudita obra de THOMPSON, J. W., The Medieval Library. Chicago, 1939 (hay reimpresión, Nueva York 1957, con un Suplemento de B. B. Boyer). Para todas las cuestiones véase el t. III del Handbuch der Bibliothekswissenschaft dirig. por MILKAU, F., Wiesbaden 1955.

${ }^{3}$ Vid. la excelente "introducción" de Thomas, M., a Febvre, L. - Martin, H. J., et alii, L'apparition du livre, n. éd. Paris 1971, págs. 17-37, y notas, págs. 457-458 («L'Évolution de l'Humanités, 30).

4 Braudel, F., "La larga duración", en La Historia y las ciencias sociales, trad. española, 1968, págs. 60-106 (“Alianza Editorial», LB 139). 
gún los hábitos tradicionales, producen, pues, siempre obras de estudio y manuscritos litúrgicos. Por lo demás, ello seguirá igual hasta el día en que la imprenta relegue definitivamente el manuscrito al dominio del pasado; e incluso después, tanto por tradición como por necesidad, los monasterios continuarán, bien entrado el siglo XVI, copiando misales, antifonarios, breviarios, etc. ${ }^{5}$.

Doblado el cabo de 1200 emerge, por tanto, un público al que el libro servirá como instrumento para enfrentarse a la vida: maestros, escolares, legistas, notarios, cortesanos y funcionarios laicos, hombres de negocios, etc., cuyo número aumenta al par que su predicamento social ${ }^{6}$. El clero y la nobleza conservarían, sin duda, por mucho tiempo sus privilegios de todo orden, culturalmente, pero desde entonces compartidos -no sin roces- con las nuevas «élites». Aunque los representantes de las mismas, en sus rangos minoritarios, se mantengan fieles a la herencia clásica, a los «antiguos», el interés de tales grupos se centra más y más en las lenguas vernáculas, es decir, en los "modernos"; que también acogen, transmiten o refunden para su divulgación el opulento legado grecolatino ${ }^{7}$. Así, el libro se populariza desde que en las Universi-

5 Thomas, M., ob. cit., págs. 21-22.

6 Los cambios operados en la sociología cultural del Bajo Medioevo, que determinarán nuevas actitudes frente a la educación y las letras, ilústranlos desde sus respectivos enfoque: AuERBACH, E., "El público occidental y su lengua», en Lenguaje literario y público en la Baja Latinidad y en la Edad Media, trad. española, Barcelona 1969, págs. 229-336 (véase, particularmente, 289 y sgs.). Paul, J., Histoire intellectuelle de lOccident médiéval. Paris, 1973. PILTZ, A., The World of Medieval Learning. Oxford 1981. WIERuszowsKI, H., The Medieval University. Masters, Students, Learning. Princeton, N. J., 1966. Deberán tenerse presentes, además, los trabajos de LE GofF, J.: La civilisation de l'Occident médiéval (cit. en la n. 1), págs. $422-423$ e ilustraciones 153 y 154; Les intellectuels au Moyen Age, 2e ed. Paris 1985, págs. I-X, 67-69, 95-97, 139-146 y 172-176; “La ciudad como agente de civilización", en CIPol..., C. M., ed., Historia económica de Europa (1) La Edad Media, trad. española. Barcelona 1979, págs. 78-114; Marchands et banquiers du Moyen Age. Paris 1956, págs. 99-124, y «Las Universidades y los poderes públicos en la Edad Media y el Renacimiento", en Tiempo, trabajo y cultura en el Occidente medieval. 18 ensayos. Trad. española, Madrid 1983, págs. 189-208. Para al contexto social y económico, véase también: HEERS, J., Occidente durante los siglos XIV y XV. Aspectos económicos y sociales, trad. española, Barcelona 1968 («Nueva Clio», 23), y SAPORI, A., Studi di storia economica, vol. III. Florencia 1967. Por su parte Maraval.L, J. A., ob. cit. (v. n. 2), se ocupa, al considerar esta fase en la Península, de "Los "hombres de saber" o letrados y la formación de su conciencia estamental» (págs. 355-389). Add. GILmore, M. P., Humanists and Jurists, Cambridge, Mass., 1963.

7 Vid. Auerbach, E. ob. y págs. cits., así como Curtius, E. R., ob. cit. (n. 1), vol. I, págs. 354-360, y II, págs. 815-818. Últimamente, quien desarrolia el tema con fortuna es Maravall, J. A., Antiguos y modernos. Visión de la historia e idea de progreso hasta el Renacimiento. 2." ed. Madrid, 1986 (“Alianza Editorial», AU 458). Comp. con BaroN, H., "La "querelle" of the Ancients and the Moderns as a Problem for Renaissance Scholars- 
dades - por exigencias docentes y científicas - el exemplar de un texto básico queda oficialmente fijado mediante la "pecia» y, gracias a ella, se reproduce merced al trabajo de innumerables copistas y al espíritu de empresa que hace del libro un solicitado artículo de consumo, tanto para el éxito profesional como para el goce literario o la devoción personal ${ }^{8}$. Respecto a los autores, cada vez más especializados - ya en latín, ya en una lengua vulgar-, dependen para su prestigio del mecenazgo, que, como en la Antigüedad clásica, los financia y promueve durante las últimas centurias medievales ${ }^{9}$. Otros hay, por supuesto, que instalan su propio taller $u$ oficina de copias, o que acuden a un librero como intermediario. De este modo, la producción y circulación de los libros a partir, sobre todo, del siglo XIII, conduce a la formación de bibliotecas reales, eclesiásticas, nobles y burguesas. La industria del libro desemboca, así, en un intenso comercio de aquél como instrumento de trabajo o como objeto suntuario -es decir, como inversión-, lo cual determina un afán coleccionista que, en sus manifestaciones eruditas y creadoras, puede calificarse de genuina bibliofilia. No se valoran solamente las obras por su temática o contenido, sino también por su caligrafía, su iluminación, su pergamino o papel, su encuadernación... Unas son joyas, otras -muchas- se leen y, por su formato reducido, manéjanse y llévanse dondequiera cómodamente. La cultura se difunde sin cesar en una sociedad cuyo dinamismo anuncia, con sus expresiones laicas y ambiciosas metas históricas, la floración renacentista.

hip", en Kristeller, P. O., And Wiener, P., eds., Renaissance Essays. Nueva York 1968, págs. 94-114.

${ }^{8}$ Sobre el libro y su circulación en los medios universitarios, véase la obra clásica de Destrez, P. J., La "Pecia" dans les manuscrits universitaires du XIIIe et du XIVe siècle. Paris 1935.

${ }^{9}$ La protección -en rigor, mecenazgo- dispensada a los escritores, adquiere durante el otoño medieval formas que prefiguran las del Humanismo y Renacimiento. Boccaccio, p. ej., dedicó su De claris mulieribus a Andreina Acciaiuoli para que ésta, una vez leído el tratado, lo difundiera entre el público más idóneo, como principal cometido del mecenas: véase Thomas, M., ob. cit. (n. 3), pág. 30 . Al mismo tiempo, el autor prevenía así las criticas malévolas. Es interesante aún, sobre tal amparo, HOLZKNECHT, K., Literary Patronage in the Middle Agges. Filadelfia 1923 (reimpr., Londres 1966). Para el mecenazgo en la Italia del Quattrocento, véase el cuadro que BURCKHARDT, J., traza en La cultura del Renacimiento en Italia, trad. española. Madrid 1941, págs. 135-142, así como von MARTin, A., Sociología del Renacimiento, trad. española. México 1946, págs. 54-83 y 121-31. Son interesantes, a su vez, las consideraciones de Hauser, A., Historia social de la literatura y el arte, trad. española, vol. I. Madrid 1957, págs. 433-34 y 470-75. 


\section{BIBLIOFILIA EN EL SIGLO XIV}

Entre los más fervorosos amantes del libro, en cualquier época, figura el tan citado autor del Philobiblon, Ricardo de Bury o de Aungerville (1287-1345), obispo de Durham y Gran Canciller de Inglaterra bajo Eduardo $1 \mathrm{II}{ }^{10}$. Es un tratado o, mejor todavía, un cántico en alabanza del libro, que revela copiosas y sabias lecturas bíblicas, patristicas, clásicas $y$, obviamente, cristiano-medievales a través de innumerables citas; unas, retóricas y, otras, muy adecuadas a tan vasta materia, enriquecidas, además, por su gran experiencia como educador y viajero, siempre atento a reunir el mayor número posible de codiciados textos. Se celebran en particular los capítulos sobre el trato delicado que merecen los libros, acerca de los malos religiosos y estudiantes de su tiempo, sobre la composición y la copia de obras claves, etc. ${ }^{11}$. Son importantes los pasajes donde el autor evoca sus andanzas de bibliófilo. Así, por ejemplo, cuando le obsequiaron o adquirió libros valiosos: "Mientras desempeñábamos - confiesa- las funciones de canciller y tesorero en la corte del ilustre e invicto Eduardo III..., y después de un primer estudio de lo concerniente a la corte y a los asuntos públicos del reino, fuimos autorizados por la bondad real para investigar con toda libertad en los rincones más apartados de la bibliotecas». Y añade: «La noticia de nuestra afición a los libros, sobre todo a los antiguos, cundió rápidamente y se difundió la especie de que nuestro favor se ganaba más fácilmente por medio de manuscritos que por medio de dinero" ${ }^{12}$. A continuación describe el estado lamentable en que se hallaban más de un scriptorium o cámara. Su vivida impresión del París escolástico es también inolvidable: «¡Oh Dios de dioses de Sión -exclama--, qué grato placer llenó nuestro corazón todas las veces que tuvimos la oportunidad de visitar París, verdadero paraíso del universo!... Alli, los días transcurren demasiado aprisa para el

${ }^{10}$ DE BuRY, Ricardo, Philobiblion. Tractatus pulcherrimus de amore librorum... Ed., introd. y trad. de H. Cocheris. París 1856. Hay trad. española de F. C. Sáinz de Robles (hijo); Filobiblión. Muy hermoso tratado sobre el amor a los libros. Madrid 1969. Vid. también la trad. de E. C. Thomas, Philobiblon. Londres, 1902. Según GHELLINCK, P. J. DE, este autor es «el que mejor caracteriza la transición hacia el humanismo», y no tanto por su estilo como por su "personal observación e individualismo...», por «una grande y cálida simpatia hacia las ideas de cultura, conocimiento y progreso humano": véase "Revue d'Histoire Ecclésiastique", XVIII (1922), 271-312 y 482-508; XIX (1923), 157-200. Para Inglaterra, véase KeR, N. R., Medieval Libraries of Great Britain, 2. ${ }^{\circ}$ ed. Londres, 1974.

${ }^{11}$ Cf. trad. española, caps. V, VI, IX, XVI, XVII, etc.

${ }^{12}$ Cf. trad. española. págs. 58-59. 
arrebato de nuestra pasión; allí existen bibliotecas que proporcionan al alma más placer que vasos con exquisitos perfumes; allí se encuentran toda clase de libros...". «También allí fue donde — concluye-, desatando las ligaduras de nuestra bolsa, repartimos a manos llenas el dinero para sacar del polvo y del cieno libros de inapreciable valor» ${ }^{13}$.

Ricardo de Bury tenía ya un sentido social de la biblioteca: «En primer lugar - dice-, todos nuestros libros - de los que hicimos un catálogo especial- los entregamos, movidos por la caridad, al Comité de estudiantes que viven en Oxford...». Seguidamente redactó un cauteloso reglamento para su préstamo, tan bien pensado que aún hoy podría ser de gran utilidad ${ }^{14}$.

Este singular prelado es, en verdad, sobresaliente, pero el siglo xIV brinda más ejemplos de bibliofilia y mecenazgo, que impulsaron la alta cultura. El rey de Francia, Carlos V, acondicionó en 1373 y en una de las torres del Louvre tres plantas como salas de su biblioteca, con un total de 917 volúmenes, que Juan, duque de Bedford -hermano de Enrique V-, compró en 1424, pero que se dispersaron por desgracia a su muerte. Disponía, al parecer, de atriles giratorios y otras comodidades para hacer grata la lectura. Recordemos también a su hermano, el duque de Berry ${ }^{15}$.

Los inventarios del Palacio de Aviñón, en 1369 y 1375, demuestran que la Corte pontificia era un centro cultural de primer orden, con más de dos mil obras que incluían autores clásicos. Benedicto XIII (Pedro de Luna) ordenó el traslado de la biblioteca, ya depuesto, a su fortaleza de Peñíscola. Finalmente, el cardenal de Foix la donó (1429) al colegio de Toulouse: constaba entonces de 1.582 códices ${ }^{16}$.

${ }^{13}$ Cf. trad. española, págs. 60-61.

${ }^{14}$ Cf. trad. española, págs. 105-107.

15 Vid. Hobson, A., Great Libraries, Nueva York, 1970, pág. 121, y MORTREUIL, T., La Bibliothèque Nationale: son origine et ses accroissements. París, 1878. DELISLE, L., estudió los inventarios del duque de Berry, de 1413 y 1416: véase The "Belles Heures" of Jean, Duke of Berry, Prince of France. With an Introduction by J. J. Rorimer. Nueva York (At The Cloisters, The Metropolitan Museum of Art), 1958.

${ }_{16}$ Para los fondos de esta Biblioteca pontificia, véase EmRle, F., Historia Bibliothecae Romanorum Pontificum tum Bonifatianae tum Avenionensis, vol. I. Roma 1890, págs. 575759, y Pelzer, A., Addenda et emendenda... Roma 1947. Sobre Benedicto XIll, véase todavía Galindo Romeo, P., La Biblioteca de Benedicto XIII (Don Pedro de Luna), lección inaugural del curso 1929-30, Universidad de Zaragoza: "Universidad" (Sept.-Oct. 1929), 4041, 54-56, 61-72 y 83-188. Posteriormente la ha investigado MAIER, A., "Die "Bibliotheca minor" Benedikts XIII (Petrus de Luna)»: Ausgehendes Mittelalter. Gesammelte Aufsätze zur Geistesgeschichte des 14. Jahrhunderts, 3 vols. Roma 1977; véase el vol. Ilf, págs. 1-53. 
En lo que respecta a la Corona de Aragón, sabemos que sus monarcas, ya desde Jaime I, gustaban de las letras y de las bibliotecas. Conocemos el inventario de la perteneciente a Jaime II (1323). Pedro IV "el Ceremonioso» había decidido pasar su colección al monasterio de Poblet, rompiendo así con la costumbre regia de alojar los libros en el archivo, la cámara, el estudio y otras dependencias o salas del palacio. «Se conservan - según $\mathrm{P}$. Bohigas- varias cartas suyas al abad de este monasterio, de los años 1381 y 1382, con instrucciones precisas sobre el local y la instalación de esta biblioteca. Tenía que tener acceso por el claustro, ser de bóveda y piedra picada y poseer bancos con atriles y cadenas para sujetar los libros. En los bancos había de haber las armas reales. Ignoramos la suerte que cupo a esta biblioteca» ${ }^{17}$. De Juan I nos informó R. Beer, publicando el catálogo de su librería, así como el de la correspondiente a Martín «el Humano» ${ }^{18}$.

Entre las privadas y famosas está la de Juan Fernández de Heredia (ca. 1300-1396), el Gran Maestre de Rodas y Castellán de Amposta ${ }^{19}$ : Juan I y Martín "el Humano" poseyeron bastantes volúmenes de aquella riquísima biblioteca, al igual que el Marqués de Santillana, como se verá luego. Deben mencionarse también la del ilustre médico y teólogo Arnau de Vilanova, cuyo inventario (1318) hace referencia a unos 200 códices, entre ellos 16 en hebreo, griego y árabe; y la del minorita fray Francesc Eiximenis $(\uparrow 1413)^{20}$.

17 BohlGas, P., El libro español (Ensayo histórico). Barcelona 1962, pág 134. Vid. también RuBio I LLUCH, A., "La cultura catalana en el regnat de Pere III" en Est. Univ. Cat., VIII (1914), 219-47.

${ }_{18}$ Vid. el catálogo de sus libros en BEER, R., Handschriftenschätze Spaniens. Viena 1894, págs. 91-95. La obra de referencia para el estado de las investigaciones sobre bibliotecas en las Coronas de Aragón, Castilla y Navarra - con datos adicionales respecto a Francia e Italia-, es la de FAULHABER, Ch. B., Libros y bibliotecas en la España medieval. Una bibliografia de fuentes impresas. Londres-Wolfeboro, N. H. (USA), 1987. Incluye, para Martín "el Humano", el inventario de sus bienes muebles, según MASSO I TORRENTS, J.

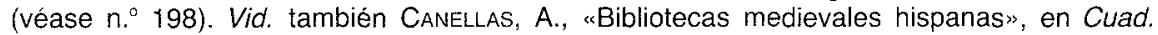
$H^{\text {a J }}$. Zurita, XXXI-XXXII (1978), 259-68.

${ }^{19}$ Cf. VIVES, J., "Juan Fernández de Heredia, Gran Maestre de Rodas. Vida, obras, formas dialectales", en Analecta Sacra Tarraconensia, 3 (1927), 121-192 (sobre todo, 133150). Para las traducciones del griego, que patrocinó, y su biblioteca, véase también LuTTRELL, A., "Greek Histories Translated and Compilated by Juan Fernández de Heredia, Master of Rhodes", en Speculum, XXXV (1960), 401-407, y LASSO DE LA VEGA, J., "Traducciones españolas de las "Vidas» de Plutarco", en Estudios Clásicos, IV (1961-62), 451514.

20 Son importantes sobre ambos: Carreras I Artau, J., "La libreria d'Arnau de Vilanova", en Analecta Sacra Tarraconensia, XI (1935), 63-84. D'ALós, R., "De la marmessoria d'Arnau de Vilanova", en Miscel.lànnia Prat de la Riba, vol. I. Barcelona [¿1923?], págs. 289-306. MonfRIN, J., "La bibliothèque de Francesc Eiximenis», Bibliothèque d'Humanisme 
En Navarra, Carlos III "el Noble» se destacó asimismo por su afición a los libros, pues se sabe que adquirió varias bibliotecas, tanto de los $\mathrm{P}$. P. dominicos de Estella como alguna que otra particular. ${ }^{21}$.

El siglo XIV castellano presenta a su vez interés, aunque no se han publicado tantos inventarios como los de la Corona de Aragón. Sin embargo, se tienen noticias sobre las colecciones reales, por ejemplo la de Alfonso XI, quien se propuso llevar a cabo un trabajo compilatorio de crónicas similar al de Alfonso «el Sabio». Una biblioteca privada muy rica, la del arzobispo Pedro Tenorio, fue donada por él en 1383 al cabildo de la catedral toledana; "constituye propiamente - dice A. Millares Carloel acta fundacional de la capitular» ${ }^{22}$.

\section{LAS NUEVAS PERSPECTIVAS CUATROCENTISTAS}

Con las primeras auras del Humanismo y durante el llamado «Prerrenacimiento» - que animan el último tercio del siglo XIV y todo el $X V$, en Castilla, pero que decaen en la Corona de Aragón a lo largo de la segunda mitad del Cuatrocientos- aumentaría la producción de libros a tono con una elevación general del nivel económico y cultural en los sectores privilegiados de la sociedad, ya se trate de la Corte y de la aristocracia, ya de los medios burgueses. Aunque la Península Ibérica no conoció una eclosión literaria, intelectual y artística tan vivaz como la Italia del "Quattrocento", porque la Edad Media seguia vigente en sus esquemas mentales y en su escala de valores, también ella adoptaría géneros, temas, formas y métodos que Italia prodigaba desde el «Trecen-

et Renaissance, XXIX (1967), 447-484 C cf. también FAUlHABER, CH. B., ob. cit. en la $n$. 18. núm. 21).

${ }^{21}$ Cf. Faulhaber, B., ob. cit. (véase n. 18), Nos. 459 (Carlos III «el Noble») y 228-229 (Príncipe de Viana).

22 Para Alfonso X1, «que mandó catar las corónicas e estorias antiguas, e falló scripto por corónicas en los libros de su cámara los fechos de los reyes que fueron en los tiempos pasados", según reza el Prólogo a la Crónica de Alfonso $X$, véase MENÉNDEZ PIDAL, R., ed., Primera Crónica General de España, que mandó componer Alfonso el Sabio y se continuaba bajo Sancho IV en 1289, vol., I. Madrid 1955, págs. XXV-XXVI. Sobre la toledana, véase Gomez Canedo, P. L., "El arzobispo D. Pedro Tenorio y la Biblioteca Capitular de Toledo",

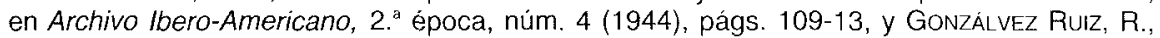
"La Biblioteca Capitular toledana en el siglo XIv", en Toletum, 2. época, núm. 6 (1973), págs. 29-56. Cf. también Miralles Carlo, A., ob. cit., en la n. 2, pag. 248. 
to" y que la Europa occidental, a su vez, recibió como fermentos de una nueva era cultural ${ }^{23}$.

$\mathrm{Ni}$ en Castilla, ni en la Corona de Aragón -tampoco en Navarra y Portugal-, se observa esa expresiva dualidad que J. Ortega y Gasset atisbó sagazmente en el hombre del siglo $\times \mathrm{V}$, válida sobre todo para Italia y parte de Europa. La lección XI de su célebre curso En torno a Galileo está dedicada, como se sabe, al siglo XV. He aquí una de sus más lúcidas y bellas páginas: «La vida en él - como toda vida en crisis- es dual en su raíz misma: por un lado es persistencia de la vida medieval o, dicho más rigorosamente, supervivencia. Por otro, es germinación oscura de vida nueva... Este hombre del siglo XV es, pues, constitucionalmente antítesis o, lo que es igual, es en todo instante lo contrario de sí mismo..."; "desarraigado de un sistema de convicciones y aún no instalado en otro, por tanto, sin tierra firme en que apoyarse y ser, sin quicio, sin autenticidad genérica. Exactamente como hoy está el hombre. Aún cree en el mundo medieval, es decir, en el trasmundo sobrenatural de Dios, pero cree sin fe viva. Su fe es ya habitual, inerte: lo cual, bien entendido, no quiere decir que fuese insincera". $Y$ añade, con su brillante e incisiva retórica: «Pero junto a esa fe consuetudinaria en lo sobrenatural, siente una confianza nueva en este mundo y en sí mismo. Empiezan a interesarle las cosas, las tereas sociales, los hombres: en suma, la naturaleza por sí misma. Las almas miran a la vez a uno y otro mundo, disociadas

${ }^{23}$ Dos autorizados panoramas sobre la gradual presencia de Italia, desde el Trecento, en los destinos culturales de Europa --muy especialmente a través de los studia humanitatis- los ofrecen: RENuCCI, P., L'aventure de l'humanisme européen au Moyen Âge (IveXIve siécles), París 1953, págs. 158-172 y notas, págs. 188-94; y GarIN, E., La educación en Europa, 1400-1600. Problemas y programas. Trad. española. Barcelona 1986, págs. 6982. En lo que atañe a la Península Ibérica, véase di CAMilo, O., El humanismo castellano del siglo XV, trad. española. Valencia 1976. FARINELLI, A., Italia e Espagna, 2 vols., Turín 1929. LOPEZ ESTRADA, F., Introducción a la iiteratura medieval española, $4 .^{a}$ ed. renovada. Madrid 1979, págs. 120-36 y 543-44. Maravall, J. A., Antiguos y modernos... (véase n. 7), págs. $239-77$ (sobre el "Prehumanismo" del siglo Xv). Las peculiares formas que estas influencias revisten en la Castilla de Juan II, Enrique IV y los Reyes Católicos, han sido objeto de atención por parte de: Round, N. G., "Renaissance Culture and his Opponents in Fifteenth-Century Castile», en Modern Language Review, núm. 57 (1962), págs. 204-215, y Russell, P. A., en "Arms versus Letters: Towards a Definition of Spanish Fifteenth-Century Humanism", en Aspects of the Renaissance: a Symposium, ed. by A. R. Lewis, Austin, Texas. Londres 1967, págs. 47-58. A su vez, GIL, L., pasa revista a las cuestiones, con certeros y agudos juicios, en Panorama social del humanismo español (1500-1800). Madrid 1981, págs. 231-47, 605-12, 664-69, 704-10, etc. Una aproximación interesante a esas relaciones es la de WIERuszowskı, H., Politics and Culture in Medieval Spain and Italy. Roma 1971; y una síntesis acerca del humanismo, en Aragón y Castilla, la ha intentado ANTElo Iglesias, A., en la Historia General de España y América, t. V, «Los Trastámara y la unidad española (1369-1517)». Madrid 1981, págs. 155-165. 
entre ambos; es decir, bizquean. Vitalmente casi todos los hombres representativos de este siglo son bizcos. $Y$ experimentamos ante ellos la peculiar desorientación en que solemos hallarnos ante un bizco, porque no sabemos bien a dónde mira" ${ }^{24}$. Se percibe aquí un cierto eco de $\mathrm{J}$. Burckhardt ${ }^{25}$. Por lo demás, Ortega coincide a su vez, en orden a tal ambivalencia, con otro clarividente pensador, N. Berdiaeff: «El hombre del Renacimiento -dice éste en un sugestivo ensayo- es un hombre desdoblado, perteneciente a dos mundos. De ahí dimanan la complejidad y la riqueza de su poder creador ${ }^{26}$.

Ahora bien, si la Corona de Aragón y, en particular, Castilla discurrían aún dentro del orden teocéntrico que informa la concepción medieval del mundo y de la vida, sin cismas en su alma, experimentaron asimismo cambios de actitud frente a la cultura; por lo menos algunos de los que afectaban a Europa en relación con el libro y las bibliotecas. También en la Península, aunque minoritariamente, se dieron análogas circunstancias favorables a ese auge de la palabra escrita; quizás por mimetismo, pero en cualquier caso importante como fenómeno colectivo. "La necesidad social del libro - advertiría igualmente Ortega- consiste en esta época en la necesidad de que haya libros, porque hay pocos. A este módulo de la necesidad responde la figura de aquellos geniales bibliotecarios renacentistas, que son grandes cazadores de libros, astutos y tenaces. La catalogación no es aún urgente. La adquisición, la producción de libros, en cambio, cobra rasgos de heroísmo. Estamos en el siglo XV». Y agrega: "No parece debido a un puro azar que precisamente en esta época en que se siente, tan vivamente, la necesidad de que haya más libros, la imprenta nazca» ${ }^{27}$.

${ }^{24}$ Ortega Y Gasset, J., "En torno a Galileo", en Obras completas, 4. ${ }^{\text {a }}$ ed., t. V, Madrid 1958, págs. 141-42.

${ }^{25}$ Cf. n. 9.

${ }^{26}$ Berdiaeff, N., Una nueva Edad Media. Reflexiones acerca de los destinos de Rusia y Europa. Trad. española, 8. ${ }^{a}$ ed., Barcelona 1938, pág. 14.

27 ORTEGa y Gasset, J., "Misión del bibliotecario", en Obras completas, ed. y t. cits., pág. 218. La penuria de libros se hacía sentir en todo el Occidente. DOMínguez Bordona, J., cita, como ejemplo significativo, el testimonio de Diego Fernández de Madrid, en 1421, aducido por GonZÁLEZ DÁvILA, Gil, Historia de la vida y hechos del rey don Henrique tercero (Madrid 1638, pág. 159), según el cual «había tanta falta de libros en Castilla, que se arrendaban por años y valían a las fábricas de las iglesias catedrales que los tenían muchos maravedís. Y... consta desta gran falta de libros que con muchos florines y trabajo no se podían haber". Cf. su ed. de PÉREZ DE Guzmán, Fernán, Generaciones y semblanzas, Madrid 1941, pág. XI (Clásicos Castellanos, 61). Para otras referencias, véase GlL, L., ob. cit. en la n. 23 , págs. $664-68$ y 670 . Sobre la revolución determinada por la imprenta, véase Febvre, L., ob. cit. en la n. 3, especialmente el cap. VIII y la bibliografía, págs. 487-510. 


\section{HUMANISMO Y BIBLIOTECAS}

Con el apasionado culto por la Antigüedad ostensible en Italia desde el "Trecento", los grandes representantes del primer humanismo y, en general, todos los cultivadores de las letras latinas, más los generosos mecenas que les protegían, se interesaron por los códices aún existentes en los monasterios y otros lugares, copiándolos o adquiriéndolos para sus colecciones privadas. Fue así como surgieron, cada vez más numerosas y estimables, las bibliotecas que, particulares o públicas, dieron su savia al Renacimiento ${ }^{28}$. Petrarca, heraldo del nuevo Humanismo, llegó a poseer una tan valiosa, que el Senado veneciano le alojó en un «palazzo" (1362-68) a cambio - en el futuro- de su biblioteca, formalmente destinada por el poeta, después de su muerte, a la república de San Marcos; noble propósito que no llegó a materializarse, pues al abandonar la ciudad por Arquà, cerca de Padua, y fallecer allí en 1374, sus libros se dispersaron ${ }^{29}$. En cuanto a Boccaccio, confió su muy selecta biblioteca a un religioso, Martino da Signa, con el encargo de permitir copias de los libros a quienquiera que lo desease; pero también esta gran colección desapareció a la muerte del fraile agustino ${ }^{30}$.

Al incrementarse los studia humanitatis y el comercio librero durante el siglo $x V$ - uno de cuyos máximos empresarios doctos fue Vespasiano da Bisticci, agente y asesor de Cosme de Médicis, Nicolás V, etc., para quienes obtenía códices y ordenaba copias en todas partes-, las bibliotecas proliferaron, entre ellas algunas tan célebres como las de los Médicis (palacio Riccardi, San Marcos, la Badia Fiesolana y, sobre todo, la

${ }^{28}$ Vid.: SabBadinI, R., Le scoperte dei codici latini e greci ne' secoli XIV e XV, 2 vols., Florencia 1905-1914, y PASQual, G., Storia della tradizione e critica del testo, 2. a ed. Florencia 1952, obras fundamentales. En lo que se refiere a Italia, FLORA, F., da una magistral visión de conjunto en su Storia della letteratura italiana, vol. I. Verona 1950, págs. 407-28. Cf. también Bolgar, R. R., The Classical Heritage and its Beneficiaries. From the Carolingian Age to the End of the Renaissance. Nueva York 1964, págs. 265-301 (Alto Renacimiento y búsqueda de Mss.) y Apéndice II (traducciones de clásicos griegos y romanos anteriores a 1600). Sobre Petrarca, véase págs. 262-63. Add: KRISTELLER, P. O., Latin Manuscript Books before 1600. Nueva York 1960.

${ }^{29}$ Acerca de Petrarca y su propósito de legar la biblioteca a Venecia, véase Petrarch. A Humanist among Princes. An Anthology of Petrarch's Letters and of Selections from his other Works. Ed. and in part translated by D. Thompson. Nueva York 1971, págs. 193-94.

${ }^{30}$ Cf. Flora, F., ob. y vol, cits. en la n. 28, pág. 292. 
que Cosme fundó en 1463, la Mediceo-Laurenziana ${ }^{31}$,) Vaticana (creada por Nicolás $V$ en 1450 , y haciendo de ella la mayor de Italia, con 1.160 volúmenes); la de Federico di Montefeltro, en Urbino (íntegramente de manuscritos, pues, según Vespasiano da Bisticci, el duque "se habria avergonzado" de tener allí libros de molde o impresos); la de Giovanni Aurispa, que en 1424 adquirió unos 250 códices de clásicos griegos; la del cardenal Bessarión, núcleo de la Marciana en Venecia ${ }^{32}$, etc.

Entre las colecciones reales se destaca la de Alfonso $V$ «el Magnánimo» (1416-1458), en Nápoles, enriquecida por Fernando I y expoliada por Carlos VIII (1495), quien se llevó al castillo de Amboise unos 1.000 volúmenes, manuscritos e impresos ${ }^{33}$. Otra muy notable fue la del soberano húngaro Matías Corvino (1458-1490), destruida por los turcos en 1540 , al conquistar Buda, y de la que se conservan como reliquias inapreciables 125 volúmenes bellamente encuadernados ${ }^{34}$.

3: Sobre el librero-humanista Vespasiano da Bisticci, véase FlorA, F., ob. y vol. cits., págs. 540-41, y las Vite di uomini illustri del secolo XV, ed. L. Frati, Bolonia 1893. Dos expresivas cartas (de Vespasiano da Bisticci a Alfonso de Palencia y la respuesta del segundo) nos sitúan en aquel ambiente literario: véase PALENCIA, Alfonso de, Epístolas latinas. Ed., pról. y trad. de R. B. Tate y R. Alemany Ferrer. Barcelona 1982, págs. 71-77. Para los Médicis, véase PINTOR, F., Per la storia della libreria medicea del Rinascimento: "Italia medievale e umanistica", III (1960), 189-212, y GuTkind, C. S., Cosimo de'Medici. Oxford 1938. La colección medicea pasó, de 158 mss. en 1456, a 1.000 en 1494.

${ }^{32}$ Para los fondos vaticanos, véase Müntz, E.,-FABRE, P., La Bibliothèque du Vatican au siècle XV d'après des documents inédits. París 1887, y Tisserano, E.,-Koch, E. W., The Vatican Library. Jersey City 1929. Cf. también PELZER, A., Codices Vaticani latimi. Roma 1933, y HoBson, A., ob. cit. en la n. 15, págs. 77-78.

33 Vid:: DE Marinis, T., La biblioteca napoletana dei Re d'Aragona, 4 vols. Milán 19471952; vol. I (1952). También, Mortreull, T., ob. cit. en la n. 15. Aunque de muy difícil localización, es importante asimismo RufFINI, M., "La biblioteca degli Aragonesi a Napoli e gli umanisti italiani dell'Accademia Alfonsina tra il 1443 e il 1458, en Analele Universităţi Bucureşti: Literatură Universală si Comparată, 20, núm. 2 (1970), 55-82.

${ }^{34}$ Cf. DE FERdinandy, M., Historia de Híungria. Madrid 1967, págs. 73-83 («Alianza Editorial», LB 46), sobre Matias Corvino: «Buda y Visegrád -escribe- se edifican y decoran magníficamente: maestros renacentistas llegan a Hungría de Italia: los 500 tomos de su biblioteca, la "Corvina", son iluminados por los mejores miniaturistas de la época" (pág. 82). Además de estas bibliotecas reales, aqui recordadas, es digna de especial mención por su riqueza la de los duques de Borgona: véase CASPAR C.-LyNA, F., Philippe le Bon et ses beaux livres, Bruselas 1944, y La Librairie de Philippe le Bon. Exhibition-Catalogue. Bruselas, Bibliothèque Royale, 1967. 


\section{BIBLIOTECAS REALES DE CASTILLA ${ }^{34 \text { bis }}$}

\section{Juan // (1406-1454)}

El que M. ${ }^{a}$ R. Lida consideró "Prerrenacimiento" español y que se extiende hasta fines del siglo $\mathrm{xV}$, alcanzando su plenitud en Castilla a mediados de esa centuria, tiene, en efecto, su culminación durante el reinado de Juan $1{ }^{35}$. El Humanismo va penetrando a la sazón en tierras castellanas, pero sin las connotaciones ético-políticas y sin el culto por la historia romana de que harían gala sus más ilustres exponentes florentinos. "Contribuía - dice bien L. Gil- al mantenimiento de las valoraciones medievales el hecho de que la antigüedad clásica no hubiera sido idealizada, como lo fue en Italia, como modelo de organización política y social, y dechado al propio tiempo de valores culturales. Los prerrenacentistas españoles (por llamarlos de una manera convencional) no sintieron ni mucho menos el mismo entusiasmo por la Roma antigua de sus contemporáneos italianos. En Juan de Mena se percibe la preferencia nacionalista por la "gótica gente que dio a España sus reyes" frente a la antigüedad romana. Incluso el fervor, cuando lo hay, se inclina hacia la antigüedad hispano-latina y no hacia la república o el imperio romanos, según era la norma de acuerdo con sus preferencias políticas entre los humanistas italianos» ${ }^{36}$. Un autor de la época que revela tal actitud, Alfonso de Cartagena, muestra además cierta objetividad y espíritu crítico al sostener que, juntamente con la tradición clásica, debe estudiarse y valorarse la herencia judeo-cristiana para entender nuestra civilización:

34 bis Cf. Los Reyes bibliófilos. Catálogo de la Exposición Junio-Sepbre. 1986. Madrid, Biblioteca Nacional, págs. 55-84.

35 «La denominación que ha hecho más fortuna --dice LóPEZ EsTRADA, F.- ha sido la de «Prerrenacimiento" español, establecida sobre el estudio de Juan de Mena; la intensificación consciente del influjo latino orienta la corriente de un humanismo, activo en la literatura romance, con importantes consecuencias estilisticas" (cf. "Características generales de la Edad Media literaria", en Historia de la literatura española, planeada y coordinada por J. M. ${ }^{a}$ Díez Borque, vol. I, La Edad Media. Madrid 1980, pág. 90). Vid., al respecto, LiDA, M. ${ }^{a}$ R., Juan de Mena, poeta del Prerrenacimiento español. México 1950. Una excelente introducción histórica y literaria a la época, es la de BOASE, R., El resurgimiento de los trovadores. Un estudio del cambio social y el tradicionalismo en el final de la Edad Media en España. Trad. espñ. Madrid 1981; cf. sobre todo págs. 69-117.

${ }^{36}$ GIL, L., ob. cit. en la n. 23, pág. 237; cf. también 238-39. 
perspectiva ésta favorecida, seguramente, por su condición de converso ${ }^{37}$.

Mas, si Castilla no vivió con igual o parecido entusiasmo el «redescubrimiento" de la Roma de Cicerón y Virgilio (el de la Grecia clásica era impensable aún, por el desconocimiento de la lengua), sin duda se abrió a las nuevas tendencias retóricas y poéticas, que a partir de Juan II informan la producción literaria en sus más cultos escritores ${ }^{38}$. La Castilla «prerrenacentista» siguió también el ejemplo de los príncipes y humanistas europeos, formando, aunque más modestamente, bibliotecas dignas de atención.

En sus Generaciones y semblanzas, Fernán Pérez de Guzmán se refiere a los gustos de Juan II, enumerándolos con laconismo: «Plaziale oyr los omes auisados e graçiosos e notaua mucho lo que dellos oya, sabia fablar[e] entender latin, leya muy bien, plazianle muchos libros e estorias, oya muy de grado los dizires rimados e conocia los viçios dellos, auia grant plazer en oyr palabras alegres e bien apuntadas, e aun el mesmo las sabia bien dizir...". "Sabia del l'arte de la musica, cantaua e tañia bien.... ${ }^{39}$.

A su vez, la Crónica de Juan // registra esas inclinaciones y aptitudes regias: «dábase mucho a leer -confirma- libros de Filósofos e Poetas», «asaz docto en la lengua latina, mucho honrrador de las personas de sciencia" ${ }^{40}$. Renombre del cual se hace eco, igualmente, mosén Diego de Valera en su Doctrinal de príncipes: “E aun en nuestros días»-se dirige a Fernando «el Católico»- «los muy excelentes príncipes de gloriosa memoria, Don Johán el segundo deste nombre en Castilla, e Don

${ }^{37}$ Sobre Alfonso de Cartagena, véase DI CAmlLlo, O., ob. cit. en la n. 23, págs. 135-80 y 203-26, y LAWRANCE, Jeremy N. H., Un tratado de Alonso de Cartagena sobre la educa. ción y los estudios literarios. Barcelona 1979. Siempre habrá que acudir, sin embargo, al $P$. L. Serrano, OSB, y a F. Cantera Burgos.

38 Vid. especialmente dI Camillo, O., Farinelli, A., Maravall, J. A., Round, N. G., Russell, P. A., Gil, L., Lawrance, N. H., cits. en las notas 23 y 36 . Sobre la Retórica y la Poética, véase FAULHABER, Ch. B., "Retóricas clásicas y medievales en bibliotecas castellanas", en Abaco, 4 (1973), 151-300, y Latin Rhetorical Theory in Thirteenth and FourteenthCentury Castile. Berkeley, Cal., 1972. Para Juan II, aparte de la clásica Antología de poetas líricos castellanos, de MEnÉndez y PeLAYo, M., (T. II, Madrid-Santander, 1944) y del aún valioso libro de Boudet DE Puymaigre, T. J., (Conde de), La cour littéraire de Juan II, roi de Castille, 2 vols. Paris, 1873, véase Rubio, F., "Don Juan II de Castilla y el movimiento humanístico de su reinado", en La Ciudad de Dios, CLXVIII (1955), 55-100.

${ }^{39}$ Cf. la ed. de J. Domínguez Bordona, cit. en la n. 27, pág. 118. Debe completarse con la ed. de R. B. Tate. Londres, 1965.

${ }^{40}$ Cit. por J. Domínguez Bordona, ed. de las Generaciones y semblanzas, págs. 11819 , ก. 19. 
Alfonso de Aragón, tíos vuestros, no menos se dieron a la moral philosophía e lengua latina e arte oratoria e poesía e ni por eso los abtos bélicos dexaron de exercer, estrenua e vigorosamente, como a todos es notorio" ${ }^{41}$.

La biblioteca del rey no es conocida suficientemente, pero sabemos que contaba entre sus preciados libros un Séneca traducido por Manuel Rodríguez de otro que Juan II prestó al conde de Benavente; «por donde se comprueba -dice el Conde de las Navas-, así como por la interesantísima portada grabada de "Las CCC» de Juan de Mena, en la que se representa al autor ofreciendo su obra al Rey Don Juan, que el padre de Doña Isabel fue tan generoso protegiendo las letras como prestando sus libros propios para que los copiasen los aficionados, con lo cual enriquecía los fondos de otras bibliotecas particulares" ${ }^{42}$. Sin embargo, la del Infante don Enrique de Aragón pasó a ser de su propiedad.

Figuraba entre sus joyas el Cancionero de Juan Alfonso de Baena, compilado "con muy grandes afanes e trabajos, e con mucha diligencia e afection e grand deseo de agradar e conplaser, e alegrar e seruir a la su grand Realesa e muy alta Señoria", como aquél asegura en la dedicatoria ${ }^{43}$. Este manuscrito, cuyas vicisitudes singulares desde la muerte de Juan II hasta 1836, en que lo adquirió - por compra- la Biblioteca Nacional de París, resultan novelescas, tiene realmente una movida historia, que su editor, J. M. ${ }^{a}$ Azáceta, expone en uno de los más sugestivos capítulos de la introducción ${ }^{44}$.

\section{Isabel la Católica (1474-1504)}

Entre las personalidades regias, no sólo castellanas sino europeas, Isabel I dio pruebas de su amor a la lectura y de su preocupación por

${ }^{41}$ Vid. Prosistas castellanos del siglo XV, I, Ed. y estudio preliminar de M. Penna. Madrid 1959, pág. 182 (BAE, t. CXVI).

${ }_{42}$ López-VAldemoro de Quesada, J. L., Conde de las Navas, Catálogo de la Real Biblioteca. Autores-Historia, 2 vols. Madrid 1910. Ct. el I, Introducción, pág. XLII. Cita la obra de SAEZ, Liciniano, Demostración historica del verdadero valor de todas las monedas que corrian en Castilla durante el reynado del señor D. Enrique III. Madrid 1796, de interés también para las bibliotecas; como la siguiente, Demostración... Enrique IV. Madrid 1805.

${ }^{43}$ Cf. Cancionero de Juan Alfonso de Baena. Ed. crítica por J. M. ${ }^{a}$ Azáceta. Vol. I. Madrid 1966, pág. 4.

${ }^{44}$ Ob. y vol. cits., págs. LXXVIII-LXXXVIII. 
elevar el nivel de la Corte a un plano superior, tanto moral como culturalmente, a tono con la nueva era. Los testimonios abundan sobre tan positivas mudanzas. Juan de Lucena, por ejemplo, comparando las bajezas del reinado anterior con la situación presente, dice: "Jugaba el Rey, éramos todos tahures; estudia la Reina, somos agora estudiantes" ${ }^{45}$. Isabel había comenzado su aprendizaje del latín hacia 1482, teniendo como profesora y consejera a Beatriz Galindo, «La Latina» ${ }^{46}$. En la quinta edición de su Gramática, dedicada a la Reina, Antonio de Nebrija daba la versión castellana -en columna paralela, a la derecha- del texto latino, porque así se lo había pedido Isabel: para que las «mugeres religiosas o virtuosas..., sin participación de varones pudieran conocer algo de la lengua latina" ${ }^{47}$. "Por desgracia -anota L. Gil-, esta importante novedad no fue respetada en ediciones posteriores, enriquecidas con comentarios y otros tratados de tema gramatical $\gg{ }^{48}$.

Fernando del Pulgar también corrobora ese interés por el estudio, que distinguió a Isabel: «Fablaba muy bien — dice-, y era de tan excelente ingenio, que en comun de tantos e tan árduos negocios como tenía en la gobernación de sus Reynos, se dió al trabajo de aprender las letras latinas; e alcanzó en tiempo de un año saber en ellas tanto, que entendía cualquier fabla o escriptura latina» ${ }^{49}$. La Reina se esforzó en inculcar a sus hijos dicha afición, cuyos frutos en Palacio ensalzaría el médico alemán Jerónimo Münzer, al visitar la Corte en 1495. Tras alabar justamente a la soberana por sus dones naturales y su preparación, reconoce impresionado la del príncipe heredero, Juan, así como la de sus hermanas: "Con la ayuda de buenos maestros - informa-, tal educación les da la madre, que es de esperar resplandezcan en sumo grado en toda clase de virtudes. El serenísimo Juan es el único hijo varón: joven de diecisiete años, que, para su edad, sabe tanto latín y es tan buen orador, que causa admiración» ${ }^{50}$.

${ }^{45}$ Vid. la Epistola exhortatoria a las letras, dirigida a Fernán Álvarez Zapata, en Opúsculos literarios de los siglos XIV a XVI, ed. A. Paz y Melia. Madrid 1892, págs. 209-19 (t. XXIX de la "Colección de Bibliófilos Españoles»). GIL, L. (ob. cit. en la n. 23) expone documentadamente la situación de Castilla bajo los Reyes Católicos, en orden a las humanidades: véase págs. $26-27,200-5,231-247,299-311$ y, para los medios bibliográficos de entonces, 606-11, 643-45, 667-68 y 706-7.

${ }^{46}$ GIL, L., ob. cit., págs. 309-310.

${ }^{47}$ GIL, L., ob. cit., pág. 99.

${ }^{48}$ GL, L. ibidem.

49 Del Pulgar Fernando, Claros varones de Castilla, ed. y notas de J. Domínguez Bordona, Madrid 1942, pág. 150 («Clásicos Castellanos», 49), pág. 150. Cf. también la ed. de R. B. Tate. Oxford, 1971.

${ }^{50}$ MÜnZER, Jerónimo, («Monetarius»), Viaje por España y Portugal, 1494-1495. Prólogo de M. Gómez Moreno. Trad. de J. López de Toro. Madrid 1951, pág. 112. 
Aunque los Reyes Católicos procuraron atraer, con tales fines, a doctos gramáticos y humanistas italianos (Pedro Mártir de Anghiera o Anglería, Lucio Marineo Sículo, etc.), la muerte de Isabel malogró tan prometedores comienzos; pues el distanciamiento entre las armas y las letras, que era muy acusado en la Castilla del siglo $x V$ debido a su conservadurismo doctrinal —opuesto a cualquier alteración de los moldes estamentales y que J. A. Maravall, N. G. Round y P. A. Russell, entre otros, han indagado certeramente-, coartaría esa política educativa orientada hacia una mayor ilustración de la nobleza, por lo menos en orden a los estudios humanísticos ${ }^{51}$. Enrique de Villena o el marqués de Santillana, para no aducir sino dos casos notables, sentíanse aislados en medio de aquella aristocracia militar que veía con recelo y disgusto la «debilitación» o pérdida del nervio, a causa de las letras reavivadas por el Humanismo. Ya Fernán Pérez de Guzmán se quejaba de que «en Castilla ovo siempre e ay poca diligençia de las antiguedades» ${ }^{52} ; \mathrm{y}$, si bien algunos magnates y caballeros procuraron estar a la altura de los tiempos, su carácter excepcional confirma la regla, es decir, la pervivencia del modelo estamental propio de la Edad Media ${ }^{53}$. El menosprecio del gramático -casi abandonado a su suerte y a unos emolumentos indignos, si no le amparaba, con limitaciones a su libertad, algún comprensivo mecenas- $y$, en general, del «hombre de letras», era la norma entre los nobles fieles a esa tradición. Incluso bajo Carlos V, durante cuyo reinado el Humanismo y el Renacimiento en España florecieron como en el resto de la Europa más culta, el joven noble debería ser el de siempre: "No quiero - hace decir Cristóbal de Villalón a uno de esos prohombres castellanos tan misoneístas - que mi hijo se subjete a las miserias de los letrados, que yo tengo rentas bastantes para le dexar cauallero: quiero que ande polido, caualgue cauallos, juste, juegue cañas, sirua damas; sepa jugar dados y naipes, blasfemar y renegar, sea hombre y sepa de todo" ${ }^{54}$.

A su vez, los clérigos y los letrados no aceptaban como «interlocutores válidos» - permítasenos la manida expresión actual- a los que se presentaban como humanistas. El cardenal Cisneros o don Pedro Gon-

${ }^{51}$ Cf. n. 23, en particular los trabajos de Gı, L., Round, N. G., y Russell, P. A., con amplias referencias.

52 Vid. las Generaciones y semblanzas, ed. J. Domínguez Bordona (n. 27), pág. 48.

${ }^{53}$ Cf. Maravall, J. A., "La concepción del saber en una sociedad tradicional» (cit. en la n. 2) y "Los "hombres de saber" o letrados y la formación de su conciencia estamental», cit. en la n. 6), passim. También GlL L. (véase n. 23), págs. 231-33.

${ }_{54}$ DE VILLaLón, Cristóbal, El scholastico, ed. J. A. Kerr. Madrid 1967, pág. 123. Cit. por Glt, L. (véase n. 23), pág. 306. 
zález de Mendoza, les protegieron ampliamente; pero estas dos grandes figuras son asimismo raras, ya que la alta jerarquía eclesiástica adoptó una actitud, según L. Gil, «de desconfianza, cuando no declaradamente hostil, frente al movimiento humanístico" ${ }^{55}$. En cuanto a los letrados $u$ «hombres de saber", los juristas al servicio de la Corona evidentemente poseían conocimientos auxiliares de historia, literatura, filosofía, etc., y contribuyeron desde la Administración a la política cultural de los Reyes: pero, como tales juristas, eran precisamente los garantes del orden estamental y de las tradiciones medievales, sin la formación privativa de los humanistas y, además, nada favorables a la promoción social de éstos ${ }^{56}$.

Pese a todo, en el siglo XV castellano la apertura cultural se manifiesta, si no con el vigor y la esperanza de los ambientes italianos ante los studia humanitatis o bonae litterae, que iban extendiéndose por el Occidente, sí, al menos, con el empuje necesario - en determinados medios selectos- para que la lectura y las bibliotecas adquiriesen cierto relieve ${ }^{57}$. Sin embargo, los Reyes Católicos no fomentaron la creación de «colecciones orgánicas de libros que pudieran servir a las minorias eruditas de instrumento de trabajo, a la manera de lo que se estaba haciendo en Italia o en Francia» ${ }^{58}$. Así, pues, tendremos que ocuparnos forzosamente de las bibliotecas particulares, que por donación de sus propietarios enriquecerian, a veces, las universitarias, como se verá a propósito de Juan de Segovia y Alfonso Ortiz, en relación con Salamanca.

${ }^{55}$ GiL, L., ob, cit., pág. 302.

56 «Tipológicamente están, pues -dice GIL, L.--, tan distantes del sabio medieval como del humanista del Renacimiento...". "Los letrados lógicamente cerraron filas sin consentir que los humanistas se salieran de la modesta función que tenían asignada desde las Partidas como "gramáticos", dejando bien sentada desde un primer momento la superioridad de las severiores disciplinae frente a las litterarum amoenitates" (ob. cit., págs. 232233).

57 «En los últimos siglos de la Edad Media -afirma BOHIGAS, P.-, con la mayor propagación del libro entre los legos y el progreso de los estudios dentro de la Iglesia, las bibliotecas se multiplicaron por doquier, dentro o fuera del recinto eclesiástico. El aumento de lectores originó asimismo los primeros intentos de organización de las bibliotecas, tanto en lo referente a clasificación de libros como a reglamentación de lectura" (ob. cit. en la $n$. 17, pág. 131). Aunque el estudio de las españolas presenta aún extensas lagunas, la muy estimable guía de FAULHABER, Ch. B. (véase $n$. 18) muestra que también en la Corona de Castilla se dio tal proceso; atenuado, sin embargo, por la escasez y el precio de los ejemplares.

${ }^{58}$ GIL, L., ob. cit. (véase n. 23), pág. 707. 
Isabel I muestra, como sus coetáneos y la documentación oficial así lo atestiguan, el buen gusto de leer e instruirse; no sólo en su vertiente religiosa o moral, sino también por noble apetencia de saberes profanos que la gobernación requería y que eran compatibles, en sus horas de ocio, con diversos géneros literarios.

La Reina no dispuso nunca de «una» biblioteca estable y organizada, sino que, por ser la Corte itinerante, los libros se hallarían repartidos entre Toledo, Madrid, Arévalo y otros lugares.

En su Elogio de la Reina Católica Doña Isabel, el erudito académico Diego Clemencín, en 1821, recoge la noticia —que el P. M. Burriel nos ha transmitido- sobre la biblioteca instalada (1477) por la soberana en el monasterio de San Juan de los Reyes, de Toledo; muy rica, al parecer, en manuscritos, destruida al ser incendiado aquél durante la invasión napoleónica y de la que no ha quedado ningún catálogo o relación de sus fondos ${ }^{59}$. Existe, no obstante, un inventario de veinte volúmenes cedidos a doña Margarita de Austria, en Granada, el 29 de septiembre de $1499^{60}$.

Sin embargo, los dos inventarios que nos permiten imaginarnos la colección regia son los de Simancas: 1) un registro de 52 volúmenes recibidos, sin fecha de entrega, por el camarero Sancho de Paredes, a quien se exigieron cuentas en 1501; y, 2) el Libro de las cosas que están en el Tesoro de los Alcázares de Segovia, en poder de Rodrigo de Tordesillas, el cual hizo Gaspar de Grizio por mandato de la reina Isabel (Segovia, noviembre de 1503), con un total de 200 libros, cuya temática es importante ${ }^{61}$. Contienen sólo una parte de la colección -formada acaso por un millar de volúmenes, aproximadamente-, ya que no aparecen obras dedicadas a la Reina por sus autores, entre ellas la Crónica de Juan II, pues Lorenzo Galíndez de Carvajal informa (1517) que se encontraba en la Recámara de Isabel, quien la tenía «en mucho precio»; pero sí figuran, en cambio, dos manuscritos valiosos (epígrafes 133 y 134 de Clemencín) en el segundo registro, de los cuales se ha perdido el primero de ellos (seguramente con las poesías completas de Alfonso Álvarez de Villasandino) e identificándose el otro con el del Cancionero de Baena.

59 Clemencin, D., «Elogio de la Reina Católica Doña Isabel», en Memorias de la Real Academia Española, VI (1821), 432 y sgs.

${ }_{60}$ Cf. Ferrandis ToRres, J., Datos documentales para la Historia del Arte español. Vol. III: Inventarios reales. Madrid 1943, págs. 59-60. SÁnChez CANTÓN, F. J. Libros, tapices y cuadros que coleccionó Isabel la Católica. Madrid 1950, pág. 18.

${ }^{61}$ Pueden verse en FerRandis, ob. y vol. cits., págs. 148-63. 
Según Clemencín, los libros del primer inventario pertenecerían, quizás, al Príncipe don Juan y a las Infantas. Por su parte, el Conde de Las Navas, director de la Real Biblioteca hasta 1931, pensaba que «esta biblioteca es, por decirlo así, la íntima de la gran Reina: mejor dicho, de la familia» ${ }^{62}$.

Isabel no se refiere a su biblioteca en el testamento, pero en 1526 el embajador veneciano Andrea Navagero afirma que los bienes de la Reina (vajillas, libros, objetos artísticos, etc.) se custodiaban en la Capilla Real de Granada, como legado suyo a la misma ${ }^{63}$. Cuando Felipe II ordenó el traslado a la biblioteca de El Escorial, en 1591, de los 130 volúmenes de esa Capilla Real -más otros de fray Hernando de Talavera-, el Cabildo se opuso, pero al fin tuvo que transigir ${ }^{64}$.

Junto con los investigadores citados, cuyas aportaciones al conocimiento del patrimonio real en tiempo de Isabel I son meritorias - tanto para las colecciones de arte como para los inventarios de libros-, hay que mencionar los trabajos de A. y E. A. de la Torre ${ }^{65}$. Entre ellos, sin embargo, es el erudito F. J. Sánchez Cantón quien más detenidamente pasa revista a las obras, identificándolas y clasificándolas por materias. Aquí nos limitaremos a señalar el interés de ciertos volúmenes, tanto manuscritos como impresos, que nos orientan acerca de los autores y temas relevantes, bien para el lector eclesiástico o seglar, especializado o humanista, de entonces, bien para la propia Reina, aunque nos movamos a veces en un terreno conjetural.

De los 400 títulos registrados, Sánchez Cantón agrupa en primer término las obras latinas, ya gramáticas y vocabularios, que están bien representados (antiguos, medievales y modernos, como los de Nebrija y Palencia), ya traducciones de Aristóteles y los clásicos romanos: faltan, no obstante, Horacio y Ovidio. Abundan igualmente las versiones al castellano, lo que demuestra su difusión entre un público interesado por la tradición clásica - sin duda cortesano-, pero carente de sólidas bases humanísticas. El Ysopet historiado o fábulas de Esopo, en la edición de

62 CONDE DE LAS NAVAS (véase n. 42), i, pág. LVII.

63 Clemencin, ob. cit., págs. 431-35, y Gallego Burín, A., La Capilla Real de Granada, Granada 1952, pág. 188.

${ }^{64}$ Cf. Zarco Cuevas, J., Catálogo de los manuscritos castellanos de la Real Biblioteca de El Escorial, vol. III, Madrid 1929, págs. 496-500.

65 Vid. de la Torre y del Cerro, A. y E. A., eds., Cuentas de Gonzalo de Baeza, tesorero de Isabel la Católica, 2 vols. Madrid 1955-56; y DE LA TORRE Y DEL CERRO, A., Testamentaria de Isabel la Católica. Valladolid 1968 (especialmente págs. 17-18, 33-34 y 158-163, para las partidas de libros). 
1489 , era una de las obras favoritas de Isabel, pese a algunos de sus grabados y a las escandalosas historietas de Poggio. También figuran el Decamerón, los Trionfi de Petrarca y cartas de Leonardo Bruni a Juan II, «que creo -dice Sánchez Cantón- desconocidas" ${ }^{66}$.

Es muy ilustrativa la relación de textos literarios en romance, desde las Cantigas alfonsies hasta los más recientes escritores; aunque, curiosamente, brilla por su ausencia el marqués de Santillana, y, en cambio - como ya se advirtió--, nos encontramos con Villasandino y el Cancionero de Baena, el Corbacho, libros de caballerías, etc. Por todo ello, Clemencín se preguntaba: « ¿Y es ésta la Princesa que se quiere pintar como de una religiosidad sombría? ${ }^{67}$.

Claro está que la espiritualidad cristiana ocupa en los inventarios un espacio privilegiado, como no podía menos de suceder: la Sagrada Escritura, los Padres de la Iglesia, los exegetas y moralistas, las vidas de Santos, los místicos, teólogos y ascetas medievales o contemporáneos, los libros de horas (hasta siete o nueve) y demás literatura devota, ofrecen un rico muestrario. Es digna de atención la presencia del Tratado de la divinanza y sus especies, por fray Lope Barrientos, contra la superstición y el ocultismo: Fernando del Pulgar nos recuerda que Isabel detestaba "sortiligeos e adevinos" ${ }^{68}$; como su padre, que ordenó a Barrientos la quema de los libros de Villena sobre tales cuestiones.

Por el contrario, escasean los tratados acerca de la Naturaleza: únicamente hallamos las Etimologías de S. Isidoro; los libros astrológicos (confundidos, en la común opinión medieval, con los de astronomía); el De proprietatibus rerum, del franciscano Bartolomé Ánglico; el Libro de las maravillas, por el ficticio viajero Juan de Mandeville, etc. ${ }^{69}$.

${ }^{66}$ Cf. ob. cit., pág. 21.

${ }_{67}$ Cf. Elogio..., pág. 44.

${ }^{68}$ Cf. Claros varones, ed. Dominguez Bordona (véase n. 49), pág. 150.

69 El De proprietatibus rerum, «en la versión castellana que Fr. Vicente de Burgos habia hecho imprimir en Tolosa de Francia el año 1494, a expensas, o con la ayuda, de los Reyes Católicos, puesto que su escudo adorna la portada y otros grabados ilustran el texto": véase SANCHEZ CANTON, ob. cit., pág. 27. Para los incunables, cf. la obra clásica de HaEBler, K., Bibliografia ibérica del siglo XV. Enumeración de todos los libros impresos en España y Portugal hasta el año de 1500. Con notas criticas por...-, 2 vols, La Haya-Leipzig 1903, y La Haya 1917. Hay reimpr.: Nueva York 1962. Del mismo autor, véase The Study of Incunabula. Nueva York 1967 (reimpr.). Es importante asimismo VINDEL, F., El arte tipográfico en España en el sigloxv, 9 vols., Madrid 1945-1953. Se añadirán como obras generales: BuEHLER, C. F., The Fifteenth Century Book. Filadelfia 1960, y FAvA. D., Manuale degli incunabuli, 2. ${ }^{a}$ ed. Milán 1953. Vid. también: García Craviotto, F., Catálogo general de incunables en Bibliotecas españolas, vol. I. Madrid 1989. 
En cambio, lógicamente, seguian influyendo los «espejos de príncipes» en sus variantes bajomedievales, junto con la literatura política (Sto. Tomás, Gil de Roma, Mosén Diego de Valera, etc.) o moral para el buen gobierno, como se aprecia en la sección correspondiente. A su lado, no faltan los autores de re militari (Vegecio), sobre la Caballería, la caza, las Ordenes militares y otros, v. gr. el famoso Libro de Ajedrez de Alfonso «el Sabio» ${ }^{70}$.

Las leyes, desde el Fuero Juzgo y las Partidas hasta las recopilaciones más recientes, los tratados de Bártolo, Baldo, etc., corren parejas en los inventarios con las crónicas y otros textos historiográficos, sobre todo del siglo xv. Una obra notable, traducida del latín, es el Tratado sobre la conquista de las islas Canarias, por el docto Alfonso de Cartagena, obispo de Burgos ${ }^{71}$.

A la reina Isabel, desde su adolescencia, le atraían los romances y la música: de ahí que también figuren un Canto de órgano y un Libro de danzas, ambos en francés ${ }^{72}$.

Hay, incluso, tres obras arábigas, entre ellas una gramática. $Y$ un Breviario sobre la sed, "que carecía de hojas —dice Sánchez Cantón-, porque era un barril cuya hechura y cuyo tejuelo disimulaban su contenido espirituoso entre tantos frutos espirituales»... ${ }^{73}$.

En la Real Biblioteca se guarda, con otros siete, un espléndido Libro de Horas, el comúnmente denominado "de Isabel "la Católica"», pues la tradición lo incluye entre los más queridos de su colección ${ }^{74}$. En todo

70 Entre las obras de carácter didáctico-moral, a la sazón bastante leídas, figuran el Doctrinal de príncipes, de Mosén Diego de Valera, muy difundido; el Libre de les dones, de Fr. Francesc Eiximenis; el De las tres virtudes para enseñamiento de las mugeres, de Cristina de Pisan; el Jardín de nobles doncellas, de Fr. Martín de Córdoba; el Corbacho o Arcipreste de Talavera; el Libro de las virtuosas e claras mugeres, de D. Alvaro de Luna; el Espejo de la vida humana, de Rodrigo Sánchez de Arévalo, etc.

${ }_{71}$ La Crónica General (siete ejemplares, entre ellos la traducción gallega); el Speculum historiale, de Vicente de Beauvais, y un Padrón grande de los Reynos e lugares de las merindades, sobresalen junto con los textos legales y los de historia coetáneos.

72 «Todos entonces, nobles y plebeyos - dice MenÉnDEZ PIDAL, R.-, sabían de memoria los romances viejos, saboreando sus tonadas sentidas y melancólicas. A fines del mismo siglo $\mathrm{XV}$ las altas clases sociales para quienes la epopeya había nacido, seguían gustando de los romances... El... de la muerte injusta de los caballeros Carvajales era uno de los que "solía oír cantar muchas veces la Reina Católica, enterneciéndose del agravio manifiesto que hizo el rey Fernando a estos caballeros" " (véase La epopeya castellana a través de la literatura española, $2 .^{\circ}$ ed. Madrid 1959, pág. 158).

${ }^{73}$ Cf. ob. cit., pág. 36.

${ }^{74}$ Libro de horas de Isabel la Católica. Estudio preliminar de M. López Serrano. Madrid 1969. 
caso, debió de pertenecer a doña Juana Enríquez, como sostiene M. López Serrano: ostenta las armas de Aragón y Enríquez, siendo muy probable que de su madre lo heredase Fernando "el Católico", y de sus padres, por tanto, Juana "la Loca» ${ }^{75}$. Ésta poseía numerosos y bellos libros devotos (once breviarios, quince misales y unos cincuenta libros de horas, ya manuscritos, ya impresos; aparte de Coplas en francés, las Epístolas de Cicerón, el Libro de las donas (¿traducción castellana del Libre de les dones, de Eiximenis? ¿El Triunfo de las donas, de Juan Rodríguez del Padrón o de la Cámara?), obras de música (28 en total), de dibujo, etc ${ }^{76}$. El Conde de las Navas dedica gran atención, sobre todo, al notabilísimo libro de horas, investigado y celebrado por muchos expertos como una obra maestra en el más puro estilo flamenco: se atribuye a Guillermo Vrelant o Wyeland, holandés cuyo taller de Brujas gozó de amplia reputación en la segunda mitad del siglo $\mathrm{XV}^{77}$.

\section{BIBLIOTECAS DE LA NOBLEZA CASTELLANA}

\section{Don Enrique de Villena (1384-1434)}

Emparentado con las Casas reales de Aragón y Castilla, este legendario personaje no pudo gozar de ningún honor cortesano, y su vida privada alimentó, con escarnios y consejas, los mentideros de entonces, adquiriendo fama de brujo por su afición al ocultismo ${ }^{78}$. Fernán Pérez de Guzmán lo caracteriza en un pasaje lapidario, al sentenciar que «naturalmente fue inclinado a las çiençias e artes mas que a la caualleria e aun a los negoçios çeuiles nin curiales...; e porque entre las otras çiençias e artes se dio mucho a la estrologia, algunos, burlando, dizian del, que sabia mucho en el cielo e poco en la tierra" ${ }^{79}$. Pero, si la fortuna no le

${ }^{75}$ Cf. ob. cit., págs. 26-28.

${ }^{76}$ Según el CONDE DE LAS NAVAS, ob. y vol. cits. (véase n. 42), págs. LXI-LXVI.

${ }_{77}$ Cf. ob. y vol. cits., págs. LXVI-LXXXIII. Cree que fue de Doña Juana Enríquez, aunque también pudo haber sido encargado por los Reyes Católicos. Vid. al respecto $M$. López Serrano, ob. cit. sobre la fecha y el artista, págs. 28-31.

${ }_{78}$ Un buen estudio biográfico y crítico sigue siendo el de Cotarelo y Mori, E., Don Enrique de Villena. Su vida y obras. Madrid, 1896. Últimamente, véase SACHS, L. F., "Enrique de Villena: a portrait of the magician as outsider", en Studies in Philology. LXIV (1967), 109-31.

${ }^{79}$ Cf. Generaciones y semblanzas, ed. Domínguez Bordona (véase n. 27), pág. 100. 
acompañó socialmente, su contribución a la literatura debe subrayarse como una de las más importantes de nuestra Edad Media: Los doce trabajos de Hércules, las primeras traducciones castellanas de la Eneida y de la Divina Comedia, el Arte de trovar (conocido sólo fragmentariamente), el Arte cisoria y el Libro de astrologia, le hacen acreedor a una justa estimación. Reunió, además, libros acerca de muy diversas materias, que E. Cotarelo y Mori trató de identificar en el apéndice III de su enjundioso, y todavía fundamental, estudio sobre Villena ${ }^{80}$.

Que la biblioteca del señor de Iniesta era extraordinaria para su tiempo, lo acredita la copla 128 del Laberinto de Fortuna, donde Juan de Mena lamenta su quema por disposición de Juan II:

Perdió los tus libros sin ser conocidos, y cómo en exequias te fueron ya luego unos metidos al ávido fuego, otros sin orden no bien repartidos... ${ }^{81}$.

Efectivamente, la Crónica de Juan II (año XXVIII, 1434, cap. VIII) expone que ael Rey mandó que le fuesen traídos todos los libros que tenía [Villena], los cuales mandó que viese fray Lope de Barrientos, maestro del Príncipe [Enrique], e viese si había algunos de malas artes; e fray Lope los miró e hizo quemar algunos e los otros quedaron en su poder». El claustro de Santo Domingo el Real, de Madrid, fue escenario de tan malhadada incineración, que, según E. Cotarelo, "debió de producir disgusto en muchas personas y murmuraciones contra el fraile, no

${ }^{80}$ Sobre sus traducciones de la Eneida y la Divina Comedia, véase la n. 88 de la Vida del Marqués de Santillana, por AMADOR DE Los Ríos, J. (Buenos Aires 1947, pág. 112; Colec. Austral, 693), que es la introducción a su edición de las Obras (Madrid, 1852). Vid. también LACUESTA, S., La primera versión castellana de la Eneida de Virgilio. Madrid 1981, y BRIDE, P. Mc., La primera versión castellana de la Divina Comedia, Madrid 1935. F. J. Sánchez Cantón editó, con un prólogo y notas, el Arte de trovar, según las citas anteriores al siglo XVIII y el extracto que de esa obra hizo, en el siglo XVI, el humanista Alvar Gómez de Castro: véase Arte de trovar... Madrid 1923, págs. 21-40. Para la biblioteca, véase CotA. RELO, ob. cit., págs. 151-75.

${ }_{31}$ DE MENA, Juan, Laberinto de Fortuna. Poemas menores. Ed. preparada por M. A. Pérez Priego. Madrid 1976, pág. 109. Vid., para sus ediciones desde la princeps (Salamanca, hacia 1481) hasta la del Brocense (Salamanca 1582), y para la glosa de Hernán Núñez, "el Comendador Griego", págs. 42-44. Cf. la n. 132 de AMADOR DE LOS RIOS, J., Vida..., sobre Lope de Barrientos. 
solamente por el hecho, sino también por el destino que se dio a los libros que no fueron quemados $>{ }^{82}$.

Fray Lope de Barrientos, mortificado acaso por las críticas, intentó exculparse en su tratado sobre la adivinación, cuando, al hablar de la magia y sus orígenes, cita un libro llamado Raziel o Razfe, y se dirige a Juan II, recordándole: «Este libro es aquel que... tú, como rey cristianissimo, mandaste a mí tu siervo e fechura, que lo quemase a vueltas de otros muchos, lo cual yo puse en ejecución en presencia de algunos de tus servidores...» ${ }^{83}$. Una obra apócrifa, el Centón epistolario de un presunto bachiller, Fernán Gómez de Cibdareal, hizo víctima a Barrientos de ese atentado; que recientemente E. Gascón Vera, en su examen del hecho, juzga una maniobra antisemítica y política, dado que las obras destruidas eran sobre alquimia, astrología y medicina, por autores árabes y judios ${ }^{84}$.

"La tarea -dice L. Gil- de depurar escritos en la hoguera la prosiguió después en San Esteban [Salamanca] el inquisidor general fray Diego de Deza, y el cardenal Cisneros en Granada con los que se tomaron

82 Cotarelo, ob. cit., pág. 111. Aduce el comentario de Zurita, J., (Anales de Aragón, libro XIV, capítulo XXII) sobre la variedad y riqueza de esta biblioteca. Cotarelo descarga a Barrientos de su responsabilidad, considerándole más bien una víctima del Centón epistolario.

83 Cf. Cotarelo, ob. cit., págs. 109-117. Ya DE PuYMaigre, T., negó existencia histórica al supuesto médico de Juan II, Fernán Gómez de Cibdareal o Ciudad Real: «Casi todos los que han hablado - sostenia - de la destrucción de los libros y papeles de Don Enrique de Villena, han tomado como punto de partida de sus acusaciones una página del Centón epistolario, colección de cartas atribuidas a Fernán Gómez de Ciudad Real, médico de Don Juan $\mathrm{II}$, y sobre cuya autenticidad se han suscitado recientemente muchas dudas»: cf. «Don Enrique de Villena et sa bibliothèque», en Revue des questions historiques, XI (1872), pág. 533.

84 GASCON VERA, E., “La quema de los libros de don Enrique de Villena: una maniobra política y antisemítica", en Bulletin of Hispanic Studies, LVI (1979), págs. 317-24. Al parecer, los códices incinerados fueron unos cincuenta, y aunque las razones alegadas en la Crónica de Juan /I apuntan a la necesidad de combatir las «malas artes" (nótese que los libros destruidos eran de astrología, medicina y alquimia, árabes y judíos), hubo intención, probablemente, de condenar y hasta de perseguir a los doctos que se interesaban, cada vez más, por los saberes profanos. En torno al monarca intrigaban elementos monásticos nada simpatizantes de las nuevas corrientes humanísticas y científicas. Vid. también la Refundición de la Crónica del Halconero, ed. por J. de M. Carriazo, Madrid 1946, págs. 170-71 (cap. XCVI, año 1434). Fr. Lope de Barrientos hace aquí un esbozo biográfico de Villena y relata la quema de esos libros. Dice de él que «fué muy grant sabio en todas çiençias, en espeçial en la Theología e Nigromançia, e avn fué grant alquimista. $Y$ con todo esto vino a tan grant menester, al tienpo que fallesçió non se falló en su cámara con que le pudiesen enterrar. $Y$ fué cosa de Nuestro Señor, porque las gentes conoscan quánto aprovechan las semejantes çiençias" (pág. 170). Sobre Barrientos, véase págs. CXXXIII$\mathrm{CLV}, \mathrm{y}$, concretamente, para la quema de los códices, págs. CXL-CXLII. 
a los moros"; quizá tres o cuatro mil volúmenes, de los cuales se salvaron, por orden del cardenal, únicamente los de medicina, entregados a la Universidad de Alcalá ${ }^{85}$.

E. Cotarelo, ante la situación calamitosa que el destino reservó a la biblioteca de Villena, con miras a su investigación trató de reconstruirla por las menciones que el autor hace en las obras llegadas a nosotros. Son 146 títulos, en su inmensa mayoría de escritores no españoles o no castellanos, citando tan sólo las Partidas, la primera Crónica General y el Libro de Alexandre. Tan sorprendentes lagunas explícanse, quizá, «por el desdén - según Cotarelo- que Don Enrique manifestaba a todo lo que no fuese griego o romano, hebreo o árabe" ${ }^{86}$, pero las obras en otras lenguas debía de tenerlas, ciertamente, en su librería. Aparte de los autores hebreos y árabes que se ocuparon de alquimia, astrología, medicina, agricultura, ciencias diversas y filosofía, el elenco es muy interesante para medir el grado de sus conocimientos sobre los clásicos antiguos y la tradición cristiana, patrística y medieval. De Aristóteles nombra casi todas las obras más notables y algunas falsamente atribuidas, pero no la Metafisica, la Física y la Política; de Platón, el Timeo, el Fedón y la República; de Jenofonte, la Ciropedia, etc. Homero es citado en sus Glosas de la Eneida, como si lo hubiera leído en griego ${ }^{87}$, lo que parece harto improbable; aunque en Aragón tuvo que haberse interesado por las traducciones del griego que el Castellán de Amposta, Juan Fernández de Heredia, había impulsado (Tucídides, Plutarco...), y la Castilla de Enrique III entraba ya en contactos políticos con el Levante bizantino, e incluso con el Gran Tamorlán, mediante la famosa embajada de Ruy González de Clavijo ${ }^{88}$.

En cambio, los escritores romanos (especialmente Cicerón y Séneca) le eran en absoluto familiares, como también los latino-medievales (sobre

${ }^{65}$ GIL, L., ob. cit., (véase n. 23), pág. 607. En la Universidad de Salamanca, el 15 de junio de 1479 , serían quemados por orden del arzobispo de Toledo, en su totalidad, los ejemplares del tratado De confessione, de Pedro Martínez de Osma. Nebrija asistió a dicho acto - como todo el claustro de profesores y alumnos- y al sermón que el dominico fray Juan de Sancti Spiritus pronunció con el enunciado Nolite sapere plus quam oportet. Cf. los comentarios de Nebrija a Cisneros: GIL, L., ob. cit., págs. 28-29.

${ }^{80}$ Cotarelo, ob. cit., pág. 152.

${ }^{87}$ Cotarelo, ob. cit., pág. 166.

${ }^{88}$ Vid. GlL, L., ob. cit., (n. 23), págs. 190-202, en las que trata del griego y de las relaciones con Bizancio entre los siglos XIV y XV. Incluso personalidades como Alfonso de Cartagena, Alfonso de Palencia, Pedro González de Mendoza, etc., se conformaban con leer a los autores griegos en su versión latina. Juan de Mena tradujo la lliada, pero la llias latina. Otro tanto cabe afirmar de Villena. 
todo San Alberto Magno) y, por supuesto, los promotores del humanismo "trecentista»: Dante, Petrarca y Boccaccio ${ }^{89}$.

\section{Iñigo López de Mendoza, Marqués de Santillana (1398-1458)}

Los estragos del tiempo y los azares a que toda importante biblioteca privada está expuesta siempre, una vez desaparecido su propietario - si no es acogida por una institución que la conserve adecuadamente-, se han hecho sentir asimismo en la suerte corrida por la del marqués de Santillana. Nuestra información sobre ella es, sin embargo, más precisa gracias a investigadores tan solventes como J. Amador de los Ríos, M. Schiff, R. Menéndez Pidal, A. Farinelli y R. Runcini ${ }^{90}$. El trabajo fundamental se reduce al gran libro de Schiff, no superado aún en su conjunto, si bien requiere matizaciones y búsquedas a tono con las ulteriores aportaciones monográficas. Fue interesante la exposición que, con motivo del quinto centenario de la muerte del Marqués, se organizó en la Biblioteca Nacional, donde se exhibieron 191 manuscritos de gran valor; pero el

89 Los escritores romanos con los que estaba, sin duda, compenetrado, son: Apuleyo (De deo Socratis), Catulo («Planto del "papagayo" de Lesbia»), Cicerón (De natura deorum, Rhetorica, De legibus, De officiis, De fato, De divinatione...), Claudiano (De raptu Proserpinae), Estacio, Eutropio, Aulo Gelio, Horacio (Epistolas), Justino (Historia), Juvenal, Tito Livio, Lucano, Macrobio, Ovidio, Plinio (¿o Lucrecio?), Séneca (tragedias, Epístolas, tratados filosóficos), Suetonio, Terencio, Vegecio y Virgilio. Obviamente, los Padres latinos y los autores medievales, cristianos (en particular, S. Jerónimo y S. Alberto Magno), debían de ocupar gran parte de su librería, junto con los árabes y judíos.

${ }_{90}$ Amador de los Ríos, J., ed.: Obras de don ínigo López de Mendoza, Marqués de Santillana. Madrid 1852. En el apéndice sobre «La biblioteca del Marqués», intenta su reconstitución ideal partiendo de las huellas que en las obras de Santillana dejaron los libros poseídos y leídos por él. - Schiff, M., La bibliothèque du marquis de Santillane. Paris 1905. Su ensayo de reconstrucción se basa en identificar los volúmenes a lo largo de cuatro siglos y medio, desde 1458 y a través de las adquisiciones de sus descendientes, pero sin consultar los archivos de la Casa de Osuna.- MENÉNDEZ PIDAL, R., «A propósito de "La bibliothèque du marquis de Santillana", por Mario Schiff, Paris, 1905", en Bulletin Hispanique, X (1908), 397-411. Importante contribución sobre diversas traducciones, entre ellas las auspiciadas por Juan Fernández de Heredia, algunos de cuyos manuscritos los adquirió Santillana. Respecto a Amador de los Ríos, dice: «...Ríos funda la reconstrucción, más que en los libros mismos, en las citas de autores esparcidas por las obras del Marqués, sistema que no es el mejor, tratándose de una biblioteca cuyos libros se conservan aún. Así sucede que la mayor parte de los volúmenes poseídos por el Marqués no aparecen mencionados en el trabajo de Ríos" (pág. 397). -FARINELLI, A., «La biblioteca del Santillana e I'umanesimo italo-ispanico", en Italia e Spagna, t. I. Turín 1929, págs. 387-425. —RunCINi, R., «La biblioteca del Marchese di Santillana, en Letterature Moderne, 8 (1958), 623-36. 
catálogo, obviamente, no da sino una idea de la colección que Santillana reunió en Guadalajara ${ }^{91}$.

El renombre del Marqués, tanto por su influencia y actuación política como por su obra poética y de mecenazgo, alcanza en los Claros varones de Castilla, de Pulgar, altura clásica: ningún autor del siglo XV, en efecto, logró transmitirnos un retrato moral del personaje, más acabado y sugestivo, que el insigne cronista. "Touo en su vida -escribe- dos notables exercicios: uno, en la disciplina militar, otro en el estudio de la ciencia; e ni las armas le ocupauan el estudio, ni el estudio le impedía el tiempo para platicar con los caualleros e escuderos de su casa...». "Era omme magnánimo, y esta su magnanimidad le era ornamento e compostura de todas las otras virtudes...». «Tenía grand copia de libros, dáuase al estudio, especialmente de la filosofía moral, e de cosas peregrinas e antiguas. Tenía siempre en su casa doctores e maestros con quien platicaua en las ciencias e lecturas que estudiaua»... «Reputaua mucho más la estimación entre los sabios, que la fama entre los muchos» ${ }^{92}$. Estos pasajes trazan en forma excelente el perfil de Santillana, aunque la única alusión a su biblioteca es fugaz.

Claro está que el propio Marqués arroja no poca luz sobre sus lecturas, y las traducciones, copias y adquisición de manuscritos por él encargadas. En la Carta a su fijo -don Pedro González de Mendoza, el futuro Gran Cardenal, que a la sazón estudiaba en Salamanca-, le dice: «A ruego e instançia mia, primero que de otro alguno, se han vulgariçado en este reyno algunos poemas, asy como la Eneyda de Virgilio, el libro mayor de las Transformaciones de Ovidio, las Tragedias de Lucio Anio Seneca, e muchas otras cosas, en que yo me he deleytado fasta este tiempo, e me deleyto, e son asy como un singular reposo a las vexaçiones e trabajos que el mundo continuamente trahe, mayormente en estos nuestros reynos" ${ }^{93}$.

91 Exposición de la biblioteca de los Mendoza del Infantado en el siglo xv, con motivo de la celebración del $V$ Centenario de la muerte de don iñigo López de Mendoza, Marqués de Santillana. Madrid, Biblioteca Nacional, 1958. El estudio es de PENNA, M.

92 DEL Pulgar, Fernando, Claros varones de Castilla (véase n. 49), págs. 38, 44 y 45. Vid, en Amador de los Rios, J., Vida... (n. 80), la n. 255, con la alabanza del Marqués por Antón de Zorita en su prólogo al Árbol de batallas. Pero los más interesantes homenajes a su memoria son, quizá, el Diálogo e raçonamiento de Pero Díaz de Toledo, su capellán y docto colaborador en tareas eruditas, y la Carta que enbió Gómez Manrique al obispo de Calahorra, sobre la muerte del Marqués, tomada por Amador de los Ríos del Cancionero de Ixar: cf. Vida..., págs. 77-81 y 144-48. Últimamente, véase PÉrez-Bustamante, R., Iñigo Lopez de Mendoza, Marqués de Santillana..., Santillana del Mar 1981.

93 Vid. la cómoda edición de los Prohemios y cartas literarias, por M. Garci-Gómez (Madrid 1984), pag. 128, según el texto establecido por Amador de los Ríos (Obras..., págs, 
Al príncipe Enrique le dedica los Proverbios de gloriosa doctrina e fructuosa enseñança, con loable franqueza: «...podría ser que algunos, los quales por aventura se fallan mas prestos a las reprehensiones e a redarguir e emendar que a façer nin ordenar, dixiessen yo aver tomado todo, o la mayor parte destos Proverbios de las dotrinas e amonestamientos de otros, asy como de Platon, de Aristotiles, de Socrates, de Virgilio, de Ovidio, de Terençio e de otros philosophos e poetas. Lo qual yo no contradiría, antes me plaçe que asy se crea e sea entendido" ${ }^{94}$.

Tan apasionado culto por la tradición clásica explica el fervor y los dispendios, cuantiosos, del Marqués al constituir su biblioteca. M. Schiff no la considera solamente como una de las primeras en abrirse al humanismo italiano, ni la aborda meramente por su riqueza: subraya, con razón, la bibliofilia exquisita del ilustre dueño. «El hombre -dice- que acopió todos estos volúmenes, haciéndolos venir a menudo de muy lejos, unía al gusto por el estudio el placer del libro. Amaba los bellos ejemplares, la vitela intachable, la escritura neta y clara, las miniaturas, las rúbricas, los títulos dorados, los medallones: todos esos pequeños lujos que un lector delicado se complace en hallar sobre los folios de los mudos compañeros de sus vigilias o meditaciones" $" 95$.

Cuando el Marqués se enteraba de que a la Corte o a manos de alguien llegaban mariuscritos de autores clásicos o «modernos», ya en latín, ya en toscano, francés o castellano, que él no poseía, inmediatamente movilizaba a sus agentes para conseguir ejemplares o realizar copias y versiones de los mismos. Tenía a su servicio muchas personas doctas y hábiles, cuyos nombres conocemos: su capellán, Pero Díaz de Toledo, que trasladó el Fedón, los Proverbios y Epistolas de Séneca, la

481-92). Sobre el "senequismo" del Marqués, cf. la sólida contribución de BLÜHER, K. A., Séneca en España. Investigaciones sobre la recepción de Séneca en España desde el siglo xIII hasta el siglo XVII. Trad. espñ. Ed. correg. y aum. Madrid 1983, págs. 186-205. Esta importante obra abarca más de lo que su título sugiere.

${ }^{94}$ Prohemios y cartas literarias, ed. M. Garci-Gómez, págs. 102-3, según el texto fijado por Amador de los Ríos (Obras..., págs. 21-28). Sobre si el Marqués sabía o no latín, véase págs. 15-20: “entendía el latín -dice Garci-Gómez- y manejaba los autores clásicos». Otros son más escépticos.

${ }_{95}$ SCHIFF, M., ob. cit., (véase n. 90), pág. LXXXIIl. La significación de Santillana en el marco prerrenacentista de Castilla, ha sido puesta de relieve por: GARCi-GómEz, M., La tradición clásica en las ideas y el estilo del Marqués de Santillana. Tesis doctoral. Washington, The Catholic University of America, 1970, y Prohemios y cartas literarias, págs. 25-53. DURÁN M., "El Marqués de Santillana y el Prerrenacimiento", en Nueva Revista de Filología Hispánica, XV (1961), 343-63. LAPESA, R., La obra literaria del marqués de Santillana. Madrid 1957. ReICHENBERger, A., "The Marqués de Santillana and the Classical Tradition en Iberorromania, I (1969), 15-34. Add.: BLÜHER, K. A., (ob. cit. n. 93). 
homilia de San Basilio sobre las letras paganas, etc.; Martín de Ávila, uno de sus escuderos y estrecho colaborador; Martín de Lucena, un converso y ahijado suyo, quien puso en romance los Evangelios y Epístolas; Alfonso Gómez de Zamora, procediendo igualmente a esa labor con las Historias de Orosio; Alfonso de Madrigal, "el Tostado", traduciendo a su vez, para Santillana, el texto latino de la Crónica Universal de Eusebio, por San Jerónimo, y comentándolo sabiamente, etc.

El propio hijo del Marqués, Pedro González de Mendoza, emprendió a instancias suyas la versión de la llias Latina, trabajo coetáneo del Omero romançado de Juan de Mena (ca. 1442); aunque, según J. Amador de los Ríos, se trata de la Ulisea. Por su parte, don Enrique de Villena, que había traducido la Eneida en 1427, pudo ofrecer a Santillana el texto castellano de la Divina Comedia solicitado por este magnate ${ }^{96}$.

En Italia contaba el Marqués con un amigo y agente, don Nuño de Guzmán, residente en Florencia, muy bien relacionado con los humanistas y libreros; también Juan de Lucena, en Roma, frecuentaba esos medios (a juicio de A. Paz y Melia, su Libro de vida beata es, más que una adaptación, casi un plagio de otra obra de Bartolomeo Fazio); el hijo segundo de Santillana, Ínigo, fue nombrado embajador ante la Santa Sede (1454-55 y 1459), bajo Nicolás $V$ y Pío II, lo que beneficiaría, sin duda, a la biblioteca de Guadalajara. Unos y otros debieron de alternar con Pier Candido Decembrio, su hermano Angelo, Leonardo Bruni, etc., tan diestros en latín como en griego; y sabemos que el Marqués empezó a comunicarse con tales círculos gracias, sobre todo, al obispo de Burgos, Alfonso de Cartagena ${ }^{97}$.

Entre las obras atesoradas en su palacio había manuscritos que provenían de otra biblioteca célebre, la del Gran Maestre de San Juan de Jerusalén o de Rodas, Juan Fernández de Heredia. Como en el caso de los libros pertenecientes a nobles italianos o de otra procedencia, las armas de su antiguo propietario aparecen raspadas, habiéndose pintado doza).

96 AMADOR DE LOS Ríos, J., Vida..., notas 88 (Villena) y 181 (Pedro González de Men-

${ }_{97}$ SCHIFF, M., págs. LXXXIV-LXXXVII. Para Nuño de Guzmán, véase el articulo de LAWRANCE, Jeremy N. H., "Nuño de Guzmán and Early Spanish Humanism: Some Reconsiderations", en Medium Aevum, LI (1982). - Sobre los contactos entre Alfonso de Cartagena y Santillana, véase también Di CAMILLO, O., (n. 23), págs. 142-90. En Prosistas cas. tellanos del siglo XV, ed. M. Penna (véase n. 41), puede verse la Questión propuesta por el Marqués al Obispo de Burgos - sobre la Caballeria como institución del Estado- y la respuesta de Cartagena: págs. 235-45, más las del estudio preliminar, por M. Penna, págs. LIX-LXVI. 
sobre ellas las de los Mendoza, con la divisa del Marqués: una celada, y por mote, «Dios e vos» ${ }^{98}$.

R. Menéndez Pidal dedujo, en sus importantes precisiones al estudio de M. Schiff, que Santillana poseyó algunos códices de Fernández de Heredia que tuvieron los reyes de Aragón Juan l y Martín «el Humano»: la traducción, al aragonés, de Plutarco; la Grant Crónica de España; las Croniques de Castella; la Segunda partida de la Grant Coronica de los Conquiridores (que corresponde a la Segona partida de Croniques dels Conqueridors de Spanya, según el inventario de Martín I)... «Don Íñigo poseyó y encuadernó con sus armas un manuscrito del Tucídides (Biblioteca Nacional, ms. 10801), traducido por orden de Heredia, manuscrito que ostenta el tamaño, la gran letra minúscula gótica y demás caracteres exteriores distintivos de otros códices de Heredia; no hay, pues, razón, como observa Schiff (págs. 19-20), para dudar que el Marqués poseyó también estos otros códices de Heredia, y más cuando observamos en ellos raspadas en la primera hoja las armas del gran maestre..., sin duda con intención de sobrepintar las armas del Marqués" ${ }^{99}$.

Una obra muy divulgada en la Edad Media, y que figuraba asimismo entre las de Guadalajara, es el Libro de Alexandre, "romanceamiento de la obra conocida con el nombre de Historia de praeliis, versión latina, hecha a fines del siglo $x$ por el arcipreste León, del texto griego del Pseudo Callisthenes" ${ }^{100}$ : Martín de Ávila, que había traducido ese libro, junto con la Comparación entre Julio César y Alejandro, de Pier Candido Decembrio, indudablemente conoció la versión latina.

El tratado de Plutarco, De toda condición de nobleza, era otro de sus libros. Al respecto, y para ilustrar con un caso expresivo la traditio clásica, R. Lapesa expone: «Esta última obra es buen ejemplo de la complicada sucesión de traslados con que se transmitían los escritos de la antigüedad, y al mismo tiempo muestra la avidez con que se recibían: vertida del griego al latín por Bonaccorso, lo fue después del latín al italiano por Angelo Decembri, a instancias del Marqués, y al poco tiempo el príncipe de Viana distraía sus pesares - «la tristeza que poseo perpetua»- poniendo en castellano la versión de Decembri» ${ }^{101}$.

${ }^{98}$ SCHIFF, M., pág. LXXXIX.

${ }^{99}$ MENÉndez PIDAl, ob. cit. (véase n. 90), págs. 406-7. Sobre el inventario de Martín «el Humano», véase la n. 18.

${ }_{100}$ Menéndez PidAl, ob. cit., pág. 400. Vid. sobre la leyenda de Alejandro y su difusión en los siglos medios: ABEL, A., Le Roman d'Alexandre, légendaire mediéval. Bruselas 1955 , y CARY, G., The Medieval Alexander. Cambridge 1956.

101 LAPESA, ob. cit. (véase n. 95), pág. 311. Cf. también LASSO DE LA VEGA, J., (n. 19) y Bravo García, A., "Cuad. de Filol. Clás.", 12 (1977), 143-85. 
Pasan de 25 las obras traducidas, para Santillana, que se conservan. Además del catálogo mencionado, sobre la exposición organizada por la Biblioteca Nacional en 1958, el de la titulada "La biblioteca del Marqués de Santillana» (Febrero, 1977), que organizó también la Nacional, es muy útil al investigador, ya que junto a los manuscritos custodiados en ella figuran los de otras bibliotecas y los perdidos. En cuanto a las obras del Marqués, tanto en la Nacional como en diversas bibliotecas, se registran igualmente con esmero, ya manuscritas, ya impresas ${ }^{102}$.

Podemos afirmar, en consecuencia, que sus fondos eran muy ricos en autores clásicos, pero quizá más, por supuesto, en textos patrísticos y medievales. Como afirma Schiff, "es aún poca cosa: la Edad Media, con su pesada carga de glosas, apostillas y crónicas, ocupa todavía un amplio espacio en la biblioteca del marqués de Santillana, pero es ya una aurora»" ${ }^{103}$.

Ahora bien, una biblioteca tan desvelada y costosamente reunida, sufrió los rigores del testamento de don Íñigo: "Ytem mando -leemos en el codicilo- que... mis libros (sino solamente ciento así latinos como de romance castellano, francés o toscano)... se benda todo en pública almoneda... para complimiento e descargo de mi ánima e para las dehudas que mando pagar...> ${ }^{104}$.

Su hijo Diego, primer duque del Infantado, prudentemente dispuso en sli última voluntad (14 de junio de 1475) que los restantes volúmenes fuesen patrimonio inalienable del mayorazgo: «E esto - añadía- porque yo desseo mucho quél et sus desçendientes se den al estudio, como el marqués mi señor, que sancta gloria aya, e yo e nuestros anteçesores lo feçimos, creyendo mucho por ellos ser cresçidas e alçadas nuestras personas e casas" ${ }^{105}$. El cuarto duque del Infantado, Íñigo López de Mendoza, se preocupó grandemente de aumentar los fondos. Pero en 1702 un incendio causó graves daños al palacio, ya que se extendió tanto a la

${ }^{102}$ Cf. Los libros del Marqués de Santillana. Catálogo de la exposición «La biblioteca del Marqués de Santillana" (febrero 1977). Madrid, Biblioteca Nacional, 1977. Para los Mss. e impresos, véase págs. 17-45.

${ }^{103}$ SCHIFF, M., pág. LXXXVI.

${ }^{104}$ Cf. Amador de los Rios, J., Vida..., n. 232, que remite al testamento, y Pérez Bus. TAMANTE, R., ob. cit. en la n. 92, págs. 69-70.

105 Ibídem, n. 234. Pedro, el futuro Gran Cardenal, llegó a reunir también una excelente biblioteca: según el inventario de 1523, constaba de 632 vols., repartidos, por materias, de este modo: 88 de religión, 115 de filosofía y moral, 22 de Derecho, más de 150 de humanidades y literatura, 62 de historia, 29 de cosmografía, 96 de medicina y 41 más entre ciencias y artes. Cf. Escolar, H., ob. cit., en la n. 2, y Merino, A., El Cardenal Mendoza, Barcelona 1942. 
biblioteca como a los archivos. Según M. Schiff, nunca sabremos con exactitud qué obras quedaron destruidas o desaparecieron: el siniestro acaso explique la ausencia de manuscritos como la versión castellana del Liber de vita et moribus philosophorum, de Walter Burleigh -esto es, una traducción o adaptación de Diógenes Laercio-, el Libro mayor de las transformaciones, de Ovidio (u Ovidio moralizado), las Tragedias de Séneca, las Etimologías de San Isidoro, etc. También, sin duda, la de las obras del Marqués, puesto que debía de haber varios ejemplares y únicamente ha sobrevivido, según Schiff —pero en un volumen misceláneo que no pertenecía a aquella biblioteca-, la Comedieta de Ponza ${ }^{106}$. "Sin embargo - advierte - no pensemos que el antiguo fondo de esta célebre biblioteca, objeto de nuestro estudio, se empobreció mucho. Hemos podido rastrear la huella de la mayoría de los libros que el marqués de Santillana verdaderamente poseyó" ${ }^{107}$. A tal fin, las propias citas o alusiones de su dueño, por lo general sinceras y claras, ayudan bastante.

En (1884) la Cámara de Diputados autorizó al Estado la compra, por 800.000 pesetas, de la biblioteca de los duques de Osuna y del Infantado, con destino a la Biblioteca Nacional. Fue así como M. Schiff, después de haberlo intentado J. Amador de los Ríos, llevó a cabo su benemérita investigación, prescindiendo de los dos inventarios —uno publicado, el otro inédito - y reconstruyendo la biblioteca del Marqués sobre un fondo constituido a lo largo de cuatrocientos cincuenta años ${ }^{108}$.

\section{Pedro Fernández de Velasco, I Conde de Haro (1399-1470)}

Fue otro de los Grandes que intervino, como Santillana, en las contiendas que agitaron a Castilla, y, como aquél, amante de los buenos libros. En un extenso estudio sobre su biblioteca - al cual se debe acudir siempre por su información de primera mano-, A. Paz y Melia nos retrató al personaje y sus gustos literarios ${ }^{109}$. El Conde, retirado en 1459 de

106 SCHIFF, M., págs. XC-XCl.

107 Ibidem.

108 Cf. Carrión, M. Catálogo de la Exposición de 1977, pág. 10.

109 PAZ y MElIA, A., «Biblioteca fundada por el Conde de Haro en 1455", en Revista de Archivos, Bibliotecas y Museos, 3. ${ }^{a}$ época, I (1897), IV (1900), VI (1902), XIX (1908) y XX (1909). DEL Pulgar, Fernando, nos presenta así al conde: «Era omme agudo e de buen entendimiento... Era omme esencial, e no curaua de apariencias, ni fazía muestras de lo que tenía ni de lo que fazía. Aprendió letras latinas, y dáuase al estudio de corónicas, e saber fechos pasados. Plazíale asimismo la comunicación de personas religiosas e de ommes sabios..., e fundó en la su villa de Medina de Pomar un monasterio de monjas de 
los negocios del mundo, formó en Medina de Pomar (Burgos) una magnífica colección: el inventario de $\mathbf{1 4 5 5}$ permite conocer las lecturas y preferencias del ilustrado magnate, sobre un total de ciento cuarenta y un volúmenes, así distribuidos: 68 de religión y filosofía moral; 37 , de historia clásica; y 26 , de crónicas, Derecho y materias diversas. Últimamente, Jeremy $\mathrm{N}$. H. Lawrance se ha ocupado de esta biblioteca en un interesantísimo trabajo ${ }^{110}$.

\section{Alfonso de Pimentel, III Conde de Benavente (1440-1461)}

R. Beer ${ }^{111}$ da noticia del inventario redactado hacia 1440(?) correspondiente a D. Rodrigo Alfonso de Pimentel, II Conde de Benavente, con 121 manuscritos que se detallan en su apariencia exterior y entre los cuales se observa una cierta selección de temas profanos. En dos artículos recientes, I. Beceiro Pita ha revisado las cuestiones sobre el III Conde, D. Alfonso, y su biblioteca familiar a la luz de las mentalidades y formas de vida nobles ${ }^{112}$. Según esta investigadora, "se conoce gracias a un inventario que no contiene ningún tipo de indicación cronológica, pero que se puede asegurar que es posterior a 1443 y debe de tener

la orden de Santa Clara, e un hospital para pobres, e dotóles de lo necesario, e allí de su voluntad se retroxo antes que muriese por espacio de dies años" (cf. Claros varones de Castilla, cit. en la n. 49 , págs. 28,33 y 34). - El barón bohemio León de Rožmithal, que recorrió la Península entre 1465 y 1467, fue recibido por el Conde de Haro. Según la relación del viaje, por el secretario Tetzel, el Conde «honró mucho a mi Señor, lo proveyó de todo lo necesario, tratándolo espléndidamente, y se maravilló sobremanera de que viniese desde tan lejos". Añade, sobre su tolerancia religiosa: "En sus tierras y hasta en su corte hay cristianos, moros y judios. A todos los deja vivir en paz en su fe. Dicen que el Conde es cristiano, pero no se sabe la religión que profesa». Vid. los Viajes por España, de Jorge de Einghen, del Barón León de Rosmithal de Blatna, de Francisco Guicciardini y de Andrés Navajero. Traducidos, anotados y con una introducción por D. A. M. Fabié. Madrid 1879, pág. 158.

110 Vid. su revisión del tema en "Nueva luz sobre la biblioteca del conde de Haro: inventario de 1455", en El Crotalón, Anuario de Filologia Española, I (1984), 1073-1111. FAULHABER, Ch. B., (ob. cit. en la n. 18, núm. 575) reseña las materias y los autores, sobre un total de 79 volúmenes, que revelan múltiples gustos y lecturas. Están representados los más notables escritores castellanos del XV.

${ }^{111} \mathrm{Cf}$. ob. cit. en la n. 18 , págs. 103-9.

112 BECEIRO, I., "La biblioteca del conde de Benavente a mediados del siglo xv y su relación con las mentalidades y usos nobiliarios de la época": En la España medieval, II: Estudios en memoria del Profesor Salvador de Moxó. Madrid 1981, págs. 135-45. Interesante aproximación. El otro estudio, más extenso y realmente informativo, es: "Los libros que pertenecieron a los condes de Benavente, entre 1434 y 1530», en Hispania (Madrid), 43 (1983), 237-80. 
como fecha tope el final del reinado de Juan ||$»{ }^{113}$. A continuación examina los " 126 ejemplares, de los cuales al menos unos 28 son comunes, además de a las colecciones de Santillana y Haro, a la mayor parte de las bibliotecas monásticas y catedralicias" ${ }^{114}$, semejanzas que también se dan en otros ámbitos de la Europa Occidental. Así, por ejemplo, las fuentes de la fe cristiana - Sagrada Escritura, Padres de la Iglesia- y los autores medievales, entre ellos Santo Tomás, Jacobo de Voragine y su Leyenda áurea (difundida asimismo con el nombre de Flos Sanctorum), Bartolomé Ánglico y su enciclopedia De proprietatibus rerum, Egidio Romano y su De regimine principum, algún libro del ciclo troyano, etc. Figuran además San Isidoro, con las Etimologías, y Boecio - muy bien representado-, junto con las habituales glosas, los florilegios y compendios. Entre los clásicos se destacan Tito Livio y Séneca; pero, en cambio, no menudean los escritores italianos, a excepción de Boccaccio. Son, en conjunto, 24 títulos, y, de éstos, 17 corresponden a autores romanos.

Un rasgo que I. Beceiro pone de relieve es la literatura jurídica -en particular las recopilaciones de Alfonso "el Sabio" y Alfonso $\mathrm{Xl}-\mathrm{y}$, con ella, las crónicas, a tenor de los gustos aristocráticos en el siglo XV, que compartirían otros estamentos, $v$. gr. los letrados ${ }^{115}$. Pero acaso la nota más saliente de la colección benaventiana sean las obras de Ramon Llull, las dedicadas a los juegos y la caza, y a los saberes prácticos relacionados con la buena administración del patrimonio. Quizás influyeran, como ha sugerido G. M. ${ }^{a}$ Bertini, los PP. franciscanos en el caso de Ramon Llull y, más expresivamente aún, en el de Juan de Gales, «que no se encuentra - dice I. Beceiro- en ninguna otra biblioteca laica hispánica de los siglos $X V$ y $X V \mid »{ }^{116}$. Hay también libros sobre agricultura y albeitería o veterinaria, de claro linaje árabe.

«En el período que abarca todo el siglo $x v$ y la primera mitad del XVI - concluye esta investigadora-, no hay una diferencia radical entre la cultura caballeresca y la clerical»... "Quizá habría que elevar, para mediados del siglo XV, el papel de la historia y las disertaciones morales, colocar la poesía épica latina en lugar de la lírica y cambiar el punto de referencia de ese pasado idealizado, por un presente pujante a nivel económico y social, pero en el que la actividad bélica exterior de los siglos pasados de la conquista contra los musulmanes es sustituida por el refinamiento cortesano, la artificiosidad y las intrigas políticas y luchas

\footnotetext{
113 Becelro, I., La biblioteca..., pág. 139.

114 Ibidem.

115 Ob. cit., pág. 141.

116 Ob. cit., pág. 142.
} 
civiles...» ${ }^{117}$. Las bibliotecas, pues, de los Grandes, de los hidalgos y de otros exponentes - a nivel inferior - de la sociedad culta castellana, contribuyen a arrojar luz sobre tal cultura caballeresca.

El hijo y el nieto del fundador, Alfonso y Rodrigo, se esforzaron en conservar la biblioteca, pero desde 1575 - al morir el VI Conde - el fondo pasó a Valladolid y, finalmente, en el siglo XIX acabó dispersándose.

\section{Fernán Pérez de Guzmán (ca. 1378- ca. 1460)}

Sobrino del Canciller Ayala y tío, por tanto, del Marqués de Santillana, este precursor del género biográfico en España, y digno poeta, fue también propietario de una selecta biblioteca en su castillo de Batres (Madrid), a donde se acogió cansado de las incesantes luchas civiles y tras una importante actuación pública. R. B. Tate, editor de las Generaciones y semblanzas ${ }^{118}$, ha anotado brevemente, pero con acertadas observaciones, el inventario de esas obras según el Ms. 5938 de la Biblioteca Nacional, de Madrid; lista que, si bien no puede identificarse, en su integridad, con la de los libros poseídos realmente por Pérez de Guzmán, sí contiene la mayoría, es decir, los de carácter histórico y moral. Como, además, no dominaba el latín, figuran aquí ocho traducciones, predominando los textos en lengua vernácula. Debió a su amistad con Alvar García de Santa María y don Alfonso de Cartagena, obispo de Burgos, así como a su estrecho contacto familiar con Santillana, versiones del hebreo y, sobre todo, de Platón, Tito Livio, Séneca y Salustio. El Ms. 1513, también de la Biblioteca Nacional y uno de los más valiosos para el estudio de nuestra historiografía -ya que incluye las crónicas desde San Isidoro hasta don Rodrigo Jiménez de Rada, el Toledano-, perteneció a Fernán Pérez de Guzmán, como ya lo hizo notar Ambrosio de Morales.

El inventario registra 29 libros y «revela —según Tate - un hombre de miras mucho más amplias de lo normal entre los nobles de su tiempo". "Desde luego - añade - como en el caso de Santillana, hay un desequilibrio entre la cantidad de información a su disposición y la em-

117 Ob. cit., págs. 144-45.

118 TAte, R. B., Prólogo (págs. XI-XII) y Apéndice I (págs. 99-101) a su ed. de las Generaciones y semblanzas, de PÉREZ DE GUZMÁN, Fernán (Londres 1965). Sobre su senequismo, véase BLUHER, K. A., ob. cit., en la n. 93, págs. 165-186. 
pleada en sus propias obras, pero, de todos modos, evidencia tal biblioteca un entusiasmo permanente por el conocimiento del pasado de su país, en particular, y de los hábitos morales del hombre, en general» ${ }^{119}$.

6. Otras bibliotecas: Pedro y Alvaro de Stúniga, Condes de Plasencia; Juan de Guzmán, III Duque de Medina Sidonia, y Pedro Fernández de Córdoba, I Marqués de Priego.

En la última década, el interés de los historiadores y eruditos por las bibliotecas - laicas y eclesiásticas - durante el siglo XV, pero también de la Alta Edad Moderna, ha producido trabajos meritorios que orientan la investigación en forma esperanzadora, tanto para Castilla como para la Corona de Aragón. En los fecundos Coloquios de la Casa de Velázquez, por ejemplo, estas cuestiones han sido objeto de muy positivo debate. Así, el dedicado, en 1980, al libro y la lectura en España y Francia durante el Antiguo Régimen: el período comprendido entre 1400 y 1520 , aproximadamente, fue abordado, entre otros, por los Profesores M. A. Ladero Quesada, C. Quintanilla Raso y C. Batlle, quienes examinan una serie de inventarios para Castilla y Cataluña, de gran importancia en orden a la cultura, ya aristocrática, ya burguesa ${ }^{120}$.

La contribución de los Profesores Quintanilla y Ladero - aunque susceptible de alguna puntualización o precisión respecto a determinadas identificaciones de autores y obras, en las partidas de esos inventarioses encomiable porque, al analizar las colecciones de cinco nobles castellanos, entre 1450 y 1518, suministran no sólo información de primera mano, documental, sino que, en un contexto sociocultural más amplio, trazan líneas metodológicas para ulteriores indagaciones.

Al reconocer la "parquedad de títulos" en la bibliografía disponible hasta la fecha, sobre todo para el siglo XV, escriben: "Los documentos son escasos, poco expresivos, y aparecen, a menudo casualmente, entre una masa archivística considerable y a la vez dispersa. Por eso, lanzarse

119 TATE, ed. cit., pág. XII. En cuanto a Fernando del Pulgar, en la Letra XXVII habla de sus 80 libros (Cf. "Clás. Cast.», 99).

120 Ladero Quesada, M. A., y Qintanilla Raso, M. ${ }^{a}$ C., "Bibliotecas de la alta nobleza castellana en el siglo XV», en: Livre et lecture en Espagne et en France sous l'Ancien Régime. Colloque de la «Casa de Velázquez». Paris 1981, págs. 47-59. Para la Corona de Aragón, véase el magistral estudio de BATLLE, C., Las bibliotecas de los ciudadanos de Barcelona en el siglo XV, coloquio cit., págs. 15-34. 
a una investigación directa en busca de relaciones de libros puede ser una empresa desmesurada y de muy poco fruto en relación con el trabajo empleado. Pero, por el contrario, dar publicidad a los hallazgos que se vayan produciendo, parece el procedimiento más seguro de acrecentar un capital de conocimientos básicos, y de valorar mejor los que ya tenemos, por vía de comparación con lo que va surgiendo" ${ }^{121}$.

Ambos investigadores aconsejan cautela en este sentido, pues la información se reduce a casos individuales, diferentes según la educación o los gustos de cada poseedor y, también, según los momentos y lugares. No es posible, en consecuencia, ni llegar a conclusiones válidas para la nobleza castellana, estamentalmente, ni siquiera -en muchos casos - fijar con exactitud el número de las obras - pues más de una se encuadernaba con otras en el mismo volumen-, ni los autores y títulos de las mismas, debido a que en los tejuelos no aparecen siempre con el rigor deseable; y los escribanos o los notarios tampoco dan muestras, a veces, de la información necesaria para transcribirlos correctamente. Tengamos en cuenta, además, si deseamos calcular el nivel de educación y cultura de aquellos nobles, que la simple posesión de libros en cantidad no es garantía suficiente de lectura real, porque, o se acumulaban de padres a hijos como bienes muebles, generalmente muy preciados - como inversión pura y simple-, o por la vanidad y munificencia del propietario cuando ejercía el mecenazgo. Sin embargo, no cabe duda que ei estudio minucioso de las bibliotecas proyecta luz sobre la curva vital de sus dueños, el estado de los conocimientos, la penetración de ideas y géneros, el número y calidad intelectual o literaria de algunos focos de cultura en la Castilla del siglo $x v$, la irrupción de modas y gustos extensivos a ciertos sectores aristocráticos, etc.

Mientras tanto, los inventarios constituyen un obligado punto de partida, y los examinados por los investigadores Ladero y Quintanilla son tan significativos como ricos.

Las dos primeras relaciones de 1454 y 1468 , corresponden a las bibliotecas de D. Pedro y D. Álvaro de Stúñiga, Conde y duque de Plasencia, respectivamente. Tiene más relieve la del segundo o, quizás, de su primera mujer, Doña Leonor Manrique; se compone de veinticinco volúmenes, entre los que sobresalen obras del dominico fray Juan López, confesor y director espiritual de aquélla, y polemista sonado contra los mudéjares de Segovia y el heterodoxo profesor salmantino Pedro de

121 Ladero-QInTANILla, ob. cit., pág. 48. 
Osma ${ }^{122}$. La mayoria de los libros que figuran en el inventario son obras devotas, pero también nos encontramos con un Regimiento de príncipes, el Calila e Digna, los Proverbios de Séneca y un tratado de mosén Diego de Valera, muy probablemente su Espejo de verdadera nobleza. Se infiere de aquí que los propietarios de esos volúmenes se interesaban, sin duda, por la temática religiosa, tanto cristiana como judeo-musulmana.

Otro Stúñiga o Zúñiga, hijo de D. Álvaro y de su segunda consorte, Doña Leonor de Pimentel, fue D. Juan, último Maestre de Alcántara y mecenas de Nebrija.

La tercera relación estudiada por los Profesores Quintanilla y Ladero, basándose en trabajos de I. Beceiro ya mencionados, atañe a la biblioteca del III Conde de Benavente. «El inventario... - dicen- no forma parte de una testamentaria, al parecer, sino de una relación de propiedades condales" ${ }^{123}$. No insistiremos aquí sobre ella, porque se ha dado ya una breve referencia a su contenido.

Otra colección, ésta muy copiosa para su tiempo, es la de D. Juan de Guzmán, III Duque de Medina Sidonia: al fallecer, en 1507, constaba de doscientos treinta volúmenes. «El ambiente cultural -observan Ladero y Quintanilla - ha comenzado a cambiar. Aunque sin ánimo de generalizar, parece que la aristocracia castellana es más culta: las bibliotecas no son ya de unas decenas o un centenar de volúmenes, sino de varios centenares. Su contenido también es relativamente distinto, siempre dentro de la fuerte singularidad de cada una de ellas" ${ }^{124}$. Presenta una fisonomía a tono con aquel momento de transición, el del primer Renacimiento, pero aún vinculado a la Castilla tradicional e influido por las corrientes flamencas. Abundan, pues, los libros de horas y de rezo, de moral, etc., junto con una "Ley Vieja", sea el Antiguo Testamento, sea - como se insínúa - un texto judío; las obras teológicas y filosóficas de la Escolástica, más un Avicena, etc. ${ }^{125}$. No hay demasiados autores clá-

${ }^{122}$ Acerca de Pedro Martínez de Osma, esclarecido maestro de Nebrija, véase Historia de la lglesia Católica, t. III («La Iglesia en la época del Renacimiento y da la Reforma católica"), por los PP. GARCia VILLOSLADA S. J., R., y LLORCA, S. J. B., 2. ed. Madrid 1967, págs. 299-301, con bibliografía. También GIL, L., ob. cit. (véase n. 23), págs. 26-29 y 6067, y MENÉndez y PELAyo, M., Historia de los heterodoxos españoles, vol. I. Madrid 1965, págs. 566-582.

${ }_{123}$ LADERO-QUINTANILLA, ob. cit., pág. 50.

${ }^{124}$ Ob. cit., pág. 51.

${ }^{125}$ Sobre Avicena y otros sabios del Islam, dice González Palencia, A.: «Basta leer las colecciones bibliográficas del siglo XVi para convencerse de que los autores traducidos en el siglo XIl siguen perpetuándose gracias a la imprenta" (cf. El Arzobispo Don Raimundo de Toledo. Barcelona, pág. 195). El Canon y demás obras de Avicena eran explicados en 
sicos, pero son escogidos, y de algunos (Salustio, César, Ovidio, Josefo, Plutarco, Aulo Gelio) poseía dos y tres ejemplares. No podían faltar, tampoco, los famosos italianos del «Trecento», ya consagrados: Dante, Petrarca y Boccaccio. En cuanto a la lengua y la literatura castellanas, están representadas especialmente por Alfonso de Palencia, Nebrija, los poetas del $X V$ y las crónicas. Figuran a su lado traducciones de los libros más leídos en Europa sobre la formación del caballero, textos legales y un tratado sobre los montes de Castilla, posiblemente de caza y montería.

Un rasgo que llama la atención, en esta biblioteca, es la cantidad de obras de carácter "científico" (aritmética, cosmografía, astronomía, ciencias de la Naturaleza, etc.), así como de medicina y cirugía, e incluso de alquimia y «arte notoria» o supuesta adquisición de ciencia infusa mediante ayunos, confesiones, etc. En total, las denominadas «ciencias ocultas» son los temas de unos treinta volúmenes, entre los cuales hay trece de alquimia y nueve de astrología, por los más conocidos autores musulmanes y cristianos, como Don Enrique de Villena.

Otra particularidad notable consiste en que se menciona tan sólo un libro «de molde», ya porque realmente la mayoría de los volúmenes fuesen manuscritos, ya porque el redactor del inventario no tuviera aún clara conciencia de lo que entrañaba la imprenta como revolución técnica y cultural.

La quinta relación de libros, los pertenecientes al I Marqués de Priego, es de 1518: la Profesora C. Quintanilla Raso le ha hecho objeto de una interesante monografía, que une a su temática el dominio, por parte de la autora, de todo lo concerniente a la Casa de Aguilar, y, en este caso, a D. Pedro Fernández de Córdoba ${ }^{126}$. El inventario consta de veinticinco folios y 268 partidas, aunque según parece eran trescientos nueve los volúmenes, y se detiene el escribano en describirlos exteriormente.

Esta biblioteca corresponde, por su variedad singular y por su criterio selectivo, a la de un humanista: además de gramáticas latinas y griegas, los clásicos antiguos - unos treinta nombres- emergen con honores, así

la Universidad de Alcalá, junto con Hipócraies y Galeno, en sendas cátedras de Medicina (cf. Bataillon, M. Erasmo y España, trad. espñ., vol. I. México 1950, pág. 15). Millás VALLICROSA, J. M., ilustra esa permanente influencia, con la familia toledana de los Castro y la medicina a comienzos del siglo xvl: véase sus Estudios de historia de la ciencia española. Barcelona 1949, págs. 443-54.

${ }_{126}$ QInTANilla Raso, C., "La biblioteca del marqués de Priego (1518)», en: En la España medieval. Estudios dedicados al Profesor D. Julio González. Madrid 1980, págs. 34783. 
como los humanistas italianos y Erasmo, aproximadamente una docena de títulos. Pero, conforme a las tendencias de la época - sobre todo en Castilla-, la Edad Media sigue muy presente con la Biblia y los grandes autores cristianos, en su infinita gama de géneros, en las crónicas, en la filosofía aristotélico-tomista, etc. Hay, no menos, obras de Derecho, Geografía, Ciencias Naturales, Agronomía y, por vivir ya en el Renacimiento, Mitología.

Finalmente, la Profesora Quintanilla procede a realizar un cálculo sobre el valor global de la biblioteca, ayudada por el precio de los libros que se anota al margen: 89.976 maravedíes, o sea, 2.440 reales, o 221 ducados ${ }^{127}$.

Esta colección debió de formarse en la segunda mitad del siglo $\mathrm{XV}$, que es cuando en la documentación de la Casa de Aguilar comienzan a mencionarse libros. El Marqués de Priego, que frecuentaba el trato de Pedro Mártir de Anglería y otros doctos varones, de los libreros en Córdoba y Valencia, tuvo que haber comprado para su colección obras importadas de Italia. Era, además, sobrino del Gran Capitán, quien seguramente había introducido sus propios libros en el círculo familiar: las partidas 190, 195 y 205 del inventario son de Bautista Mantuano, Pedro

Gravina y Cantalicio, autores que ensalzan las gestas napolitanas de aquél ${ }^{128}$.

\section{BIBLIOTECAS PRIVADAS DE ECLESIÁSTICOS}

1. Juan de Segovia (1393-1458)

Aunque se conocen otras librerías como la del obispo de Burgos, D. Luis de Acuña, estudiada por N. López Martínez ${ }^{129}$, o la de D. Juan

\footnotetext{
${ }^{127}$ Ob. cit., págs. $352-53$.

${ }^{128}$ Ob. cit., págs. 354-55. Los trabajos de LADERO QUESADA, M. A., y QINTANILLA RASO, C., aquí considerados, invitan a explorar tan dificultoso campo y, a la vez, divulgan los conocimientos actuales sobre las bibliotecas privadas de Castilla. Su esfuerzo a este propósito es digno de todo elogio, pues al dominio de las fuentes documentales unen la preocupación humanística en su más amplio y noble sentido. No obstante, como ambos investigadores advierten, muchas de las autorias y materias de tales inventarios deben acogerse con prudente reserva, ya que no siempre resulta fácil y clara su atribución o identificación. Caben, pues, errores y omisiones por los motivos que dichos Profesores aducen: prisas, cuando no ignorancia, de los escribanos; títulos en el tejuelo vagos e incompletos; encuadernación de varias obras en un mismo volumen, etc. Por todo ello, estamos unos y otros expuestos a diversos azares. Trataré, pues, de señalar en el Apéndice algunos autores y obras que exigen ciertas precisiones.

129 «La biblioteca de Don Luis de Acuña en 1496», en Hispania, 20 (1960), 81-110.
} 
Bernal Díaz de Luco - que cae fuera de nuestros límites cronológicos-, investigada por el P. T. Marín ${ }^{130}$, ricas también en obras clásicas y medievales, debe recordarse aquí la del teólogo Juan de Segovia. Profesor en Salamanca y cuyo papel en el Concilio de Basilea - junto con su preocupación por el Islam a efectos misionales, en la línea de las artes praedicandi- han subrayado H. Haller, L. Cristiani, el P. D. Cabanelas, O. F. M., etc., llegó a reunir una importante biblioteca ${ }^{131}$. De ella se han ocupado el Profesor Julio González y B. Hernández Montes ${ }^{132}$.

Juan Alfonso González de Segovia, que tales son su nombre y apellidos, tuvo por compañeros o alumnos en la Universidad de Salamanca a figuras tan destacadas como Lope de Barrientos, Alfonso de Madrigal o «El Tostado», Rodrigo Sánchez de Arévalo, etc., quienes compartían con él la vida académica hacia 1421; habiendo estado allí, antes que él, Alfonso de Cartagena y otros personajes famosos. Enseñó Sagrada Escritura, pero sus comisiones en Castilla y en el extranjero, desde 1426, le impidieron la dedicación exclusiva. Hallándose en Medina del Campo, el año 1431, entabló memorable discusión con un sabio musulmán, granadino, sobre Jesucristo y el misterio de la Trinidad, manifestándose ya su interés por la fe coránica. A partir de entonces, tras una comisión en Roma ante Eugenio IV y el regreso a Castilla, entre 1432 y 1433 asiste, como único delegado salmantino, a las sesiones del Concilio de Basilea, cuyas vicisitudes relataría en una obra fundamental ${ }^{133}$, siendo muy respetadas su ciencia e intervenciones, entre otros por Nicolás de Cusa y Eneas Silvio Piccolomini (Pío II). Alli arribó la embajada de Juan II, con un enviado tan eminente como Alfonso García de Santa María (Alfonso de Cartagena), y al Concilio acudió también otro buen teólogo, Juan de

130 "La biblioteca del obispo Juan Bernal Díaz de Luco (1495-1556" y «La biblioteca... Lista de autores y obras", en Hispania Sacra, V (1952), 262-326, y VII (1954), 47-84.

131 Haller, H., Concilium Basileense. Studium und Quellen. 7 vols. Basilea, 1896-1926. -Cristianl, L., s. v. "Bâle, concile», en Dictionnaire de Droit Canonique, dirig. por Villien. Magnin. Paris, 1924 y sgs. - Cabanelas, D., OFM, Juan de Segovia (1393-1458) y el problema islámico. Madrid 1952.

${ }_{132}$ González, J., El maestro Juan de Segovia y su biblioteca. Madrid 1944. - HeRnánDEz Montes, B., ed., Biblioteca de Juan de Segovia: edición y comentario de su escritura de donación. Madrid 1984. Es el principal trabajo hasta la fecha.

133 Vid. la titulada Historia gestorum generalis synodi Basiliensis, en: PALACKY, F., BiRK, E., y BEER, R., eds., Monumenta Conciliorum generalium saeculi XV, 4 vols. Viena 18571935 (vol. IV). Junto con Juan de Ragusa, Juan de Segovia es quien aporta la documentación de primera mano sobre el Concilio. También deben consultarse: GOMEZ CANEDO, L., OFM, Un español al servicio de la Santa Sede: Don Juan de Carvajal, cardenal de Sant'Angelo, legado en Alemania y Hungría (1399?-1469). Madrid 1947, y BELTRÁN DE HEREDIA, V., O. P., "La embajada de Castilla en el Concilio de Basilea y su discusión con los ingleses", en Historia Sacra, X (1957), 5-31. 
Torquemada. El profesor salmantino, que empezaba a participar en los debates (27-VIII-1434), defendió el dogma de la Inmaculada Concepción, e intervino activamente - desde una posición moderada- a favor del Concilio y en contra de Eugenio IV. Fue nombrado por el nuevo Papa, Félix V, cardenal de San Calixto (12-X-1440), y, nueve años más tarde, Nicolás $V$-restaurada ya la autoridad pontificia sobre la conciliar- levantaba las penas que habían recaído sobre Félix $V$ y sus partidarios. Habiendo sido despojado del capelo cardenalicio, Juan de Segovia, ahora obispo de la diócesis Mauraniense, en Saboya (1451), fue "trasladado" a la de Cesarea como arzobispo: «Este nombramiento - dice J. González- debió hacerse por el deseo de honrarle y por las intenciones que él tenía de retirarse del mundo" ${ }^{134}$. En efecto, gracias a las rentas concedidas, pudo gozar al fin venturosamente, en el priorato de Aiton, de una paz fecunda, entregado de lleno al estudio y a su biblioteca.

Porque ésta, una colección apreciable, se explica en función de su vida salmantina y europea. Contrariamente a las bibliotecas reales y de la nobleza -salvo honrosas excepciones-, los libros de estos otros propietarios responden plenamente a su formación literaria e intelectual, tanto como a sus recursos profesionales o beneficios eclesiásticos, y, sobre todo, a su vocación y quehaceres; de tal modo, que la biblioteca es para ellos consustancial a su vida. Así, pues, cada libro está íntimamente asociado a una experiencia humana, real, del propietario, o a una obra escrita por éste. La biografía de Juan de Segovia es, así, la historia material y espiritual de su biblioteca.

Conocemos, en parte, su contenido merced a la escritura de donación de la misma que hizo, el 9 de octubre de 1457, a la Universidad de Salamanca ${ }^{135}$. Se trata de una relación detallada y, por lo demás, con interesantes reflexiones y noticias sobre los libros: consérvase en el Ms. 211 de la Biblioteca Universitaria de esa ciudad, pero no en el original, sino en una copia imperfecta. "El códice - según J. González-es de la segunda mitad del $\mathrm{XV}$, y es como un cartulario selecto de la Universidad para uso de sus autoridades del $\mathrm{XV}$, y conservación de textos tan importantes" ${ }^{136}$.

La donación consta de 80 autores identificados y de unos 305 títulos de obras, distribuidos todos ellos en 92 partidas. Juan de Segovia puso

134 GonzÁlez, J., ob. cit., pág. 76.

135 Cf. González, J., ob. cit., págs. 137-190, con los Índices, págs. 193-211; pero, sobre todo, Hernández Montes, B., ob. cil., págs. 28n-29n, 43, 84-109, 111-13, 268 y 282.

136 González, J., ob. cit., pág. 131. 
condiciones: «que no se vendan o enajenen; que se guarden en la biblioteca, fijos por cadenas, a no ser que se copien o ingresen otros semejantes o iguales; los más preciados se guardarían en el arca del tesoro" ${ }^{137}$. Como avezado bibliófilo, sabía que los libros no sometidos a precauciones son sicut passeres in monte ab arbore in arborem facile transmigrantes ${ }^{138}$. Defendía, por ello, la biblioteca pública o común, y pensó que su amada Universidad - de la que nos ha dejado un bello elogio en su discurso de Basilea, cuando se discutió allí la reforma de los estudios - era la institución adecuada para albergarla con ciertas seguridades. Pero, desgraciadamente, una colección tan valiosa para ese tiempo sufrió también la dispersión, habiéndose identificado solamente unos 12 manuscritos de la copiosa donación. «De momento -concluye J. González- cabe la sospecha de que su voluntad no se cumpliera por entero y que algunos pasaran a otros destinos. La pérdida de alguno o de la mayoría por parte de la Universidad nada debe extrañarnos si tenemos en cuenta los préstamos, el derrumbamiento de su bóveda en el XVII, los robos, el aprovechamiento de algunos códices para encuadernaciones durante el XVI, con el consentimiento del claustro, etc.» ${ }^{139}$.

Entre los volúmenes que Juan de Segovia tenía en gran estima figuraban una Biblia moralizada; un Corán antiguo (llamó a un alfaquí de Segovia, Yuça Bidelli, para realizar en Aiton, y en equipo, una versión crítica del Corán); un calendario "del tiempo de los paganos", copiado por él; un Liber de gestis et decretis Constanciensis concilii; los Decreta Concilii Basiliensis, y un Liber epistolarum et responsionum synodalium, etc ${ }^{139}$ bis.

En la donación figuran 29 obras de Juan de Segovia, especialmente sobre teología e historia (la del Concilio de Basilea, sin duda su producción más celebrada aún), entre las que se cuenta un nutrido cartapacio.

\section{Rodrigo Sánchez de Arévalo (ca. 1400-1470)}

Este prelado y alcaide de Sant'Angelo, cuyos escritos circularon en Castilla y todo el Occidente como obras de un erudito polígrafo, acredi-

\footnotetext{
137 GonzÁlez, J., ob. cit., págs. 132-33.

${ }_{138}$ Cf. GonzÁlez, J., ob. cit., págs. 142-43.

139 GonzÁlez, J., ob. cit., págs. 134-135.

139 bis GonZÁLEZ, J., ob. cit., págs. 128-29.
} 
tado especialmente por sus tratados en defensa de la causa pontificia durante la crisis conciliar, sobre teología, moral, política e historia hispánica, llegó a reunir una biblioteca que, ya en su casa de Burgos, se admiraba ${ }^{140}$. J. M. ${ }^{2}$ Laboa afirma ser de D. Rodrigo cuatro códices de la Biblioteca Vaticana y da una interesante referencia de su contenido, útil para la historia del humanismo italiano, con epístolas suyas y dirigidas a él por autores famosos, discursos, etc. El Ms. Vat. Lat. 1018, además de obras de Juan de Gales, Petrarca, Leonardo Bruni y Egidio Romano, incluye la apócrifa carta del emperador Constantino al Papa Silvestre y unas Annotationes (De Tamerlane), que confirman el parentesco de Rodrigo Sánchez de Arévalo con Ferrand Sánchez de Palençuelos (o Fernán Sánchez de Palaçuelos), quien con Payo Gómez de Sotomayor integró la embajada de Enrique III de Castilla a la Corte de Timur Leng o Tamerlán (1403-1406), y en cuya misión viajó Ruy González de Clavijo, su narrador ${ }^{141}$.

${ }^{140}$ Vid. LaBoA, J. M. ${ }^{a}$, Rodrigo Sánchez de Arévalo, alcaide de Sant'Angelo. Madrid, 1973, pág. 322. Sobre esta gran figura véase, además: TRAME, R. H., Rodrigo Sánchez de Arévalo, 1404-1470. A Spanish Diplomat and Champion of the Papacy. Washington 1958, y ANTELO IGLESIAS, A., "La Ciudad ideal según fray Francesc Eiximenis y Rodrigo Sánchez de Arévalo», en La ciudad hispánica durante los siglos XIII al XVI. Actas del Coloquio celebrado en La Rábida y Sevilla, del 14 al 19 de Septiembre de 1981. Vol. I. Madrid 1985, págs. 33-50.

${ }^{141}$ Cf. LABOA, J. $\mathrm{M}^{\mathrm{a}}$, ob. cit., págs. 322-24. Sobre sus ascendientes, véase págs. 2527, y la notable Embajada a Tamorlán. Estudio y edición de un manuscrito del siglo XV, por LÓPEZ EstRadA, F., (Madrid 1943), págs. 4 y 253 sgs., donde el personaje aparece también como Hernán Sánchez de Palaçuelos. -Aunque nos hemos propuesto comentar en este trabajo únicamente las bibliotecas privadas de figuras importantes, omitiendo por ahora las monásticas, las catedralicias y las de las Ordenes Militares, debemos aludir siquiera, aquí, a la del convento de Calatrava, con 438 volúmenes y 123 autores identificados, según el inventario de 1526, si bien debía de haber 100 volúmenes más anotados en las hojas que faltan. La ha estudiado CASADO QUINTANILLA, B., «La biblioteca del sacro convento de Calatrava", en Espacio, tiempo y forma (Madrid), Serie III (Historia Medieval), 2 (1989), 65-120. Ella revela con elocuencia el alto nivel de cultura teológico-filosófica, jurídica, histórica y literaria de los Maestres y freyles de Calatrava. Recordemos, como expresiva muestra de tolerancia e ilustración, el encargo de verter al castellano la Biblia, que hizo el Maestre don Luis de Guzmán al Rabbi Moshé Arragel, de Guadalajara (1422-1433 aprox.), parece ser que con la colaboración del primero: véase su ed. por el Duque de Alba, según la transcripción de A. Paz y Melia y J. Paz, vol. I. Madrid 1922. CASTRO, A., menciona otros casos: don Lorenzo Suárez de Figueroa, Maestre de Santiago, mandó a don Jacob Çadique de Uclés, ya bautizado, que tradujese del catalán al castellano el Libro de sabios e philosophos e de otros ejemplos e doctrinas muy buenas (1402), quizá semejante al Libre de saviesa, del judío catalán Yafuda (cf. La realidad histórica de España. México 1954, pág. 215, núm. 20, y el cap. XIII). Volviendo a la biblioteca de Calatrava, la nómina publicada de autores clásicos y humanistas italianos asciende a veinticinco, de primera fila todos. El resto de los volúmenes corresponde a las materias propias del estado eclesiástico y, obviamente, de la milicia. 


\section{Alfonso Ortiz y la Universidad de Salamanca}

Si la donación de Juan de Segovia a la biblioteca de la Universidad de Salamanca fue muy importante, la de Alfonso Ortiz merece consignarse también como la de un gran benefactor para esa ilustre comunidad académica ${ }^{142}$. El doctor Ortiz, cuyo Liber dialogorum sobre la virtud y el placer dedicó al arzobispo de Toledo, Alfonso Carrillo, durante su formación en Roma a mediados del siglo XV tuvo ocasión de frecuentar los círculos humanísticos, al igual que su compatriota Juan de Lucena, autor del De vita beata, con el que mantuvo una larga enemistad ${ }^{143}$. La controversia, en Italia, acerca de la ética epicúrea y la estoica en sus relaciones con la moral cristiana (para el sentir eclesiástico, esas escuelas paganas equiparábanse a los saduceos y fariseos), polémica en la que entraron figuras tan destacadas como Lorenzo Valla y Bartolomeo Fazio, particularmente, arrastró no menos a los castellanos, dando lugar así a los respectivos tratados de Lucena y Ortiz ${ }^{144}$. En tanto que el primero se limitó a traducir y adaptar el De vitae felicitate de Fazio, el segundo hizo obra más personal, si bien ecléctica, pues ensaya en ella una concepción liberal de la ética cristiana, distante por igual del ascetismo y de la racionalización teológica propios de la Edad Media, y de las posiciones humanísticas «paganizantes» ${ }^{145}$. G. M. ${ }^{a}$ Bertini ha sometido a un riguroso análisis el tratado de Ortiz, que $\mathrm{O}$. Di Camillo - según se lamenta- no pudo consultar en la biblioteca del Cabildo de Burgo de Osma ${ }^{146}$, pero cuyos comentarios sobre tales cuestiones litigiosas son muy dignos de atención.

Este doctor Ortiz, como Juan de Segovia, poseía una rica biblioteca que legó a la Universidad de Salamanca en 1505. Los libros llegaron en

${ }^{142}$ Sobre este autor, véase BERTINI, G. M. ${ }^{\mathrm{a}}$, «Un diálogo humanístico sobre la educación del príncipe don Juan", en Fernando el Católico y la cultura de su tiempo. Zaragoza 1961, págs. 37-62. O. Di Camillo (véase ob. cit., en la n. 23, págs. 250-52 y 261-65), que sigue al investigador y crítico italiano en su presentación de Ortiz, consigna el dato de que la biblioteca donada a Salamanca constaba, según Bertini, de más de 600 volúmenes, aunque otros cálculos superan el millar: véase infra, n. 147.

${ }_{143}$ DI CAMILLO, ob. cit., págs. 251-52.

144 D। CAMILLO, ob. cit., págs. 244-50. Vid. también la ed. del Libro de vida beata, por BerTINI, G. M. ${ }^{2}$, en Testi spagnoli del s. XV. Turín 1950, págs. 97-182.

145 Di Camillo, ob. cit., pág. 263.

146 Di CAMILLO, ob. cit., pág. 250: "Esta obra - dice, refiriéndose al Liber dialogorumse halla ahora en el Cabildo de la Catedral de Burgo de Osma. No habiéndonos sido permitido examinarla, nuestras observaciones sobre la misma se basan en la incompleta información dada por Giovanni Maria Bertini, quien, más afortunado que nosotros, ha visto y leído el manuscrito.» 
32 bultos que pesaban 130 arrobas y fue necesario construir un local ad hoc ${ }^{147}$. Bajo el cardenal Cisneros, quien donó manuscritos y papeles al Colegio de S. Ildefonso, en Alcalá, y posteriormente, otros insignes representantes del Alto Renacimiento español (Hernán Núñez a Salamanca, Alvar Gómez de Castro a Toledo, Juan Ginés de Sepúlveda a Córdoba, etcétera) dejaron sus libros a los cabildos de sus preferencias ${ }^{148}$.

Pero la Universidad de Salamanca resultó ser la más favorecida en tan generosas decisiones. A tal punto, que su Biblioteca se agrandaría y embellecería desde finales del siglo $\mathrm{xv}$, al paso que sus fondos, acrecentados por las donaciones o adquisiciones, constituirían en el siglo XVI un venero de información para la ya numerosa familia académica. El médico alemán Jerónimo Münzer, en 1495, se haría lenguas de la ciudad y de su casa de estudios: "Entre los anejos del claustro - dice al evocar su estancia invernal, de diciembre a enero- está la biblioteca, semejante a la cual no he visto todavía ninguna en España. Es un edificio soberbio, abovedado a manera de iglesia, con antiquísimos y magníficos libros en pergamino acerca de todas las facultades, especialmente de Filosofía y Teología». Y agrega, sobre el Estudio: "Cuando yo lo visité, me aseguraron que asistían a las clases unos cinco mil estudiantes entre todas las Facultades... Tiene un bellísimo colegio recientemente construido a expensas del rey, de piedra y silleria, a la manera de los claustros de los monasterios, con amplias, luminosas y bien adornadas cátedras. Posee, también, una gran librería abovedada, y pintados en su parte superior los signos del Zodíaco y las artes liberales. Es de grande como la capilla de la bienaventurada Virgen de Nuremberg. Vimos a los estudiantes leyendo y recitando las lecciones... Me agradó mucho este Estudio. Hay otros más en España, como el de Valladolid, el de Lisboa y el de Toledo; pero en nada se igualan a éste» ${ }^{149}$.

El testimonio del andariego Münzer es veraz y entusiasta. Más tarde, Pedro de Medina, en su Libro de grandezas y cosas memorables de España (1548), describiría la ciudad del Tormes y su famosa Universidad con el mismo espíritu, pero más detalladamente. El pasaje merece transcribirse. «Hay una librería - afirma-, la mejor de España: ábrese dos horas cada día; está en ella un púlpito, donde está un hombre mirando que ningún libro se saque della. Estas escuelas mayores son tan sumptuosas y de tan hermosa y rica obra que sóla la portada y el cuarto de

147 Beltrán de Heredia, P., Cartulario de la Universidad de Salamanca, 4 vols., 1970-

72; cfr. el II, pág. 213 (según GIL, L., ob. cit., en la n. 23, pág. 709, n. 15).

${ }^{148}$ Cf., GIL, L., ob. cit., pág. 708.

149 MÜNZER, Jerónimo, ob. cit., (véase n. 50), págs. 87-88. 
la librería se dice costó a la fábrica más de treinta mil ducados. En estas escuelas mayores es una capilla muy rica de bóveda; en lo alto de ella está pintada toda el astrología del cielo. Aquí es un reloj que es cosa notable, cuya campana es muy grande y encima de ella un negro que da las horas, están dos carneros que dan la media hora; encima del mostrador del reloj, está una imagen de nuestra Señora y debajo de la imagen, los tres reyes magos y dos ángeles, los cuales todos se humillan a nuestra Señora a las nueve horas de la mañana; así mesmo está la luna que por sus puntos hace su movimiento, creciendo o menguando donde se ve conforme cómo cada día parece en el cielo" ${ }^{150}$.

La simbólica iconografía de aquella biblioteca ha suscitado el interés de los historiadores del arte. El Profesor S. Sebastián, entre ellos, la ha investigado cumplidamente. ${ }^{151}$. Basándose en la cosmovisión renacentista según diversos autores - sobre todo A. Chastel-, pero teniendo presente asimismo la tradición medieval en orden a la astrología - según $O$. Green y Ch. R. Post-, asocia ese trasfondo cosmológico-emblemático, tan complejo, con la decoración pictórica de la biblioteca salmantina atribuida a Fernando Gallego, y propone como marco cronológico para su ejecución el lustro 1485-90; advirtiendo que no es posible documentar con exactitud ese notable trabajo artístico y alegórico-simbólico, porque faltan las fuentes primarias, de archivo, para el lapso 1481-1503, aunque existan varios testimonios - como los de J. Münzer, Lucio Marineo Sículo y $P$. de Medina - que permiten imaginarnos los frescos en su totalidad $^{152}$. El Profesor Sebastián ha identificado la obra que, por sus grabados, influyó en la temática y estructura de la decoración: el Poeticon astronomicon, de Cayo Julio Hygino (Venecia, 1485). No obstante, el realizador, seguramente Fernando Gallego, supo interpretar con talento dichos grabados: «Esta inspiración - dice - no afectó a la personalidad del pintor castellano, pues... sólo le sirvieron de punto de partida, él supo insuflarles su estilo y fuerza expresiva, quedando perfectamente empa-

150 De Medina, Pedro, Libro de grandezas y cosas memorables de España. Libro de la verdad, ed. y prólogo de A. González Palencia. Madrid 1944, cap. LXXXIX, pág. 132.

151 SEBAStián, S. Y CoRtés, L., Simbolismo de los programas humanísticos de la Universidad de Salamanca. Salamanca 1973. Vid. también, del primero, Arte y humanismo, Madrid 1978, págs. 138-48 y 167-69. En gracia de la exactitud conviene puntualizar que Pedro de Medina - al menos en la edición de A. González Palencia, antes citada- habla, sí, de «toda el astrología del cielo", pero no de que "están pintadas y labradas de oro las cuarenta y ocho imágenes de la octava esfera, los vientos y casi toda la fábrica y cosas de la astrología»; como Gaya Nuño, A., Fernando Gallego. Madrid 1958, pág. 36, transcribe y S. Sebastián reitera en Arte y humanismo (pág. 141).

${ }^{152}$ Sebastián, S., Arte y humanismo, pág. 168. 
rentados con su pintura. Fernando Gallego hizo, en la madurez de su producción, esta obra» ${ }^{153}$.

\section{CONCLUSIÓN}

A modo de balance, el estudio sintético que de las bibliotecas reales, nobiliarias y eclesiásticas en sus casos más representativos, hemos intentado aquí, durante las últimas centurias medievales - muy particularmente el siglo $X V$ castellano-, permite contemplar un panorama tan variado como sugestivo.

Desde que el libro fue introduciéndose en los medios universitarios y burgueses, a partir del siglo XIII, también su acción cultural se haría sentir en los círculos cortesanos, regios y aristocráticos de la Europa Occidental. Con los aurorales brotes humanísticos, el Renacimiento promoveria la localización de manuscritos con obras de autores clásicos y, en seguida, la febril impresión de múltiples libros que un ávido público demandaba. Las primeras bibliotecas, modestas en sus fondos - salvo las de algunos monarcas y magnates-, darían paso a otras privadas, cada vez mayores $\mathrm{y}$, al propio tiempo, reveladoras de los cambios producidos en la temática y las mentalidades.

Así, por ejemplo, la colección isabelina que los inventarios conservados nos muestran, incompleta, revélase característica de esa transición del mundo medieval a la nueva era; en Castilla, como se ha visto, menos problemática y agitada culturalmente que en la Italia del Quattrocento. Sin embargo, también la Reina Católica gustaba de géneros y lecturas cuya difusión, en el Occidente, impulsaba el Renacimiento, así como su Corte acogía —al igual que la de Alfonso $V$ «el Magnánimo», en Nápoles- a los humanistas de España y foráneos.

En cuanto a las bibliotecas de los nobles ilustrados, la constituida por D. Enrique de Villena, tan infortunada, debió de ser extraordinaria para su época en autores no sólo cristianos, judíos y musulmanes, sino también clásicos, según los conocimientos y aficiones - un tanto peregrinas- de su versado propietario. Respecto a la del Marqués de Santillana, medieval y «prerrenacentista» a la par, superó ciertamente a otras

153 Sebastián, S., ob. cit., pág. 142. 
coetáneas, entre ellas las del Conde de Haro y el III Conde de Benavente, nobles espíritus ya abiertos a las influencias del primer humanismo en sus grandes figuras italianas. La biblioteca de Guadalajara fue, sin duda, la más rica literariamente y, a la vez, un centro de traducciones y comunicación al servicio del Marqués, tan generoso mecenas como poeta eximio. Conocemos en parte sus fondos gracias, sobre todo, a Mario Schiff, cuya aportación sigue orientando las investigaciones, ampliadas últimamente a otros nobles castellanos, como los Stúñiga, Medina Sidonia y Priego, asimismo importantes a juzgar por los inventarios publicados.

Entre las eclesiásticas, hemos puesto de relieve las pertenecientes a Juan de Segovia y Alfonso Ortiz, benefactores de la Universidad salmantina con sus pingües donaciones de libros.

Como el excelente repertorio bibliográfico de Ch. B. Faulhaber lo acredita, el trabajo en este campo avanza esperanzadoramente. Las monografías aparecidas sobre otros personajes y sus bibliotecas, desbrozan el camino hacia obras de síntesis, que trazarán las líneas maestras del proceso cultural en la Corona de Castilla; permeable, durante el siglo xv, a las corrientes y modas europeas en la vida del espíritu, aunque -como ya se ha expuesto- fiel todavia, y por más de dos siglos aún, a las tradiciones medievales. Uno de los temas que serán, a buen seguro, revisados, el de la antítesis o tensión entre las armas y las letras, entre la concepción militar de la vida propia de una nobleza forjada en el yunque de la Reconquista y la visión intelectual o humanística privativa de las nuevas "élites" - ya laicas, ya eclesiásticas-, dependerá en gran medida de nuestra información sobre el número y calidad de las bibliotecas, así como de la extensión y asuntos de las lecturas en los círculos rectores. Verdad es que las perspectivas se han ensanchado y aun modificado en este sentido, pues disponemos de materiales e investigaciones muy precisas, estadística y cualitativamente -recordemos tan sólo, aquí, las observaciones de B. Bennassar y J. Pérez sobre las «resistencias mentales" en orden al atraso económico de España, y que se remontan a la Alta Edad Moderna con sus secuelas medievales- ${ }^{154}$, para confiar en que, aplicando métodos rigurosos, el estudio de los progresos educativos y el de las mentalidades, en todos los estamentos, dará sazonados frutos.

${ }^{154}$ Cf. Bennassar, B. y otros, Origenes del atraso económico español, trad. española. Barcelona 1985, págs. 147-204. 


\section{APÉNDICE}

Como ya se advierte en la nota 128 del presente artículo, es inevitable hacer unas cuantas observaciones respecto a algunos de los autores y obras que los Profesores M. A. Ladero Quesada y C. Quintanilla Raso tratan de identificar o, en ciertos casos, omiten en sus valiosos trabajos sobre las bibliotecas de D. Pedro y D. Alvaro de Stúñiga, conde y duque de Plasencia, respectivamente; D. Alfonso de Pimentel, III conde de Benavente, según los datos suministrados por la Profesora I. Beceiro; D. Juan de Guzmán, III duque de Medina Sidonia, y D. Pedro Fernández de Córdoba, I marqués de Priego (véanse notas 120 y 126). Es, lo admitimos, empresa arriesgada ésta de atribuir tal o cual título -simplemente por la referencia, muchas veces apresurada, inexacta o vaga, que del mismo se da en la partida del inventario- a un autor conocido; o identificar la obra, si se trata de un anónimo, por el, a menudo, impreciso tejuelo del volumen. Sin embago, con espíritu constructivo y, en última instancia, con el fin de que otros investigadores dedicados a este género de pesquisas - tan apasionantes como arduas - puedan aportar nuevos materiales y luces, nos aventuramos a terciar en el empeño escogiendo, para ello, diversos ejemplos de interés.

I. Los inventarios correspondientes al conde y duque de Plasencia (1454; A. H. N., Osuna, leg. 21510 (1), el primero; y 1468, A. H. N., Osuna, leg. 2166 (2), el segundo), incluyen, para D. Pedro, "un "libro del marmotreto", cuyo contenido - dice uno de los Profesores, ob. cit. en la n. 120, pág. 49- no consigo imaginar». ¿Será, quizás, el Mamotreto de fray Giovanni Marchesini, O. F. M., de Módena, obra de consulta para la Sagrada Escritura y el Oficio Divino, muy difundida e impresa, por tal razón, tempranamente en Maguncia (1470)? Figura entre los libros de Isabel «la Católica» (cf. SÁNCHEZ CANTÓN, F. J., OB. CIT., en la n. 60). Al ocuparse de los primeros incunables, FebVre, L. y Martin, H. J. (OB. CIT., en la n. 3, pág. 353) mencionan como obras muy solicitadas «las compilaciones medievales (concebidas frecuentemente en forma de léxicos o diccionarios)...; por ejemplo, el Catholicon de Giovanni Balbi, el Mammetractus (sic) de Giovanni Marchesini, y aun la Historia escolástica, de Pedro Comestor'. Por su parte, Renaudet, A., en Prerreforme et huma- 
nisme à Paris pendant les prémières guerres d'italie (1494-1517) (Paris, 1916, págs. 28 y 57), alude a los Ebrardos, Mamotrectos, Papías, Uguccios, etc., que proliferaban a fines del siglo xv. Vid. también BatallLoN, M. -quien cita a A. Renaudet--, Erasmo y España, trad. espñ., vol. I, México, 1950, pág. 37, n. 37, a propósito de Nebrija.

En cuanto a los proverbios de Séneca (quizá la traducción de Pedro Díaz de Toledo), texto "escrito de molde» que se consigna en el inventario de D. Álvaro de Stúñiga, "es, si no me equivoco - añade uno de los Profesores, ibidem-, una de las menciones castellanas más antiguas a libros impresos". Efectivamente, pues, si el Sinodal de Aguilafuente (Segovia) se considera el libro impreso (¿1472?) más antiguo de España (anterior a los de Zaragoza, 1473, y Valencia, 1474), esa edición de los Proverbios atribuidos en la Edad Media a Séneca, de localizarse algún dia, vendría a renovar completamente las perspectivas sobre la introducción del arte tipográfico en nuestra Península y, desde luego, sobre las primeras ediciones de Séneca: cf. BLÜHER, K. A., ob. cit. en la n. 93, págs. 233-36. La edición princeps, "casi íntegra», de las obras completas de Séneca es la del catalán Blas Romero, del monasterio de Poblet (Nápoles 1475), como ya indicó MENÉNDEZ Y PELAYO, M., Bibliografía hispano-latina clásica, vol. VIII, Santander 1952, págs. 43-44. Habría que esperar hasta la primera edición crítica, de Erasmo (Basilea, 1529), para disponer de un corpus senequiano expurgado - en parte- de los apócrifos medievales. Respecto a los Proverbios y a su primera impresión conocida, vid. BLÜHER, ob. cit., págs. 67-75, 132-55, 165-68, 187-88 y 236 (la fecha de impresión aquí anotada es, en Zamora, 1482).

La Biblioteca Nacional, de Madrid, posee un ejemplar de las Partidas (Mss., sig. Vit. 4-6), con «notable encuadernación de cuero oscuro con hierro mudéjar y forro de terciopelo", y miniaturas en las que se imitan «los modelos góticos franceses e italianos", según la noticia que ilustra el núm. 114 del Catálogo de la Exposición sobre Alfonso $X$ (organizada en Toledo, junio-septiempre 1984), Madrid, Ministerio de Cultura, 1984, pág. 157, con bibliografía. El Ms. es del siglo xV y perteneció a D. Alvaro de Stúniga, primer duque de Arévalo, y a los Reyes Católicos. No se alude a él.

II. Si examinamos la relación (A. H. N., Osuna, 4210, doc. 2), que los Profesores Ladero y Quintanilla comentan (págs. 50-51), del IIl conde de Benavente, D. Alfonso de Pimentel, forzoso es evocar a su padre, D. Rodrigo Alfonso de Pimentel, iniciador de la biblioteca, cuyo catálogo 
—añadiendo otros volúmenes- se redactó, acaso, entre 1443 y 1454. En el inventario estudiado por I. Beceiro «hay amplio espacio dedicado a la literatura medieval castellana, catalana e italiana» (pág. 50). Esa afición perduraría en el nieto, Rodrigo, para quien fue escrito el códice hoy conservado en la Real Biblioteca (Ms. 2-J-3) - no antes de 1476, al parecer-, con el famoso Cancionero de Gómez Manrique. La Biblioteca Nacional guarda otro un poco anterior a éste: cf. Tesoros de España. Diez siglos de libros españoles. Madrid, Ministerio de Cultura, 1986, núm. 81, pág. 177 (Catálogo de la Exposición organizada, bajo ese epígrafe, en la Biblioteca Nacional, junio-septiembre 1986).

Entre los libros de teología y filosofía propiedad del III Conde de Benavente, se anotan dos «De Sumo bonum» (sic) (pág. 50), de S. Isidoro de Sevilla. Es sabido que en la tradición manuscrita reciben dicho título (por las tres palabras del comienzo, "De summo bono...») los Sententiarum libri tres del arzobispo hispalense: cf. San Leandro, San Isidoro y San Fructuoso, trad. de J. Campos e I. Roca, Madrid 1971 (B. A. C., núm. 321; "Santos Padres españoles", II) y DíaZ Y DÍAZ, M., "Isidoro en la Edad Media", en Isidoriana. Estudios sobre S. Isidoro de Sevilla en el XIV Centenario de su nacimiento, León 1961, especialmente págs. 38086 (del siglo XIII al XV).

Se mencionan, además, "algunos ejemplares de la "Ética" de Santo Tomás de Aquino" (pág. 50); i.e., probablemente su comentario a la Ética a Nicómaco (1266), pues no se conoce ningún tratado del "Doctor Angélico" con aquel título. Cf. MANDONNET, P., Les écrits authentiques de saint Thomas d'Aquin, Friburgo de Br., 1910, y GrabmanN, M., Les Commentaires de saint Thomas d'Aquin sur les ouvrages d'Aristote (separata de los "Annales de I'Institut Supérieur de Philosophie», Lovaina 1914), págs. 231-81. También, de este gran especialista, la Historia de la Teología católica. Desde fines de la Era Patrística hasta nuestros días. Basada en el Compendio de M. J. Scheeben. Trad. española, Madrid 1946, págs. 94-104, donde no figura tal Ética. Otro resumen de Grabmann, M., al efecto, es su Filosofía medieval, trad. española, Barcelona 1949 (reimpr.), págs. 93-94 (Colec. Labor, 177). A menos que, en la partida del inventario, "Ética» encubra la XVI quaestio disputata "De Malo", lo que parece bastante dudoso *.

\footnotetext{
* Podría tratarse, quizá, de la Moral tomista que en la Summa Theol. es desarrollada, según sus principios fundamentales, en la Prima Secundae, y, de manera especial, en la Secunda Secundae, junto con la ascesis.
} 
El ejemplar de los, así denominados en el inventario, "Dicta filosoforum» (pág. 50), bien pudiera ser uno de tantos florilegios o sentenciarios de ascendencia oriental y pseudo-clásica, tan difundidos en la Europa medieval: cf., para la bibliografía, BLÜHER, K. A., ob. cit. en la n. 93, págs. 71-77 (sobre su recepción en la Península, durante los siglos xill y XIV). Entre los autores más favorecidos estaban Juan de Gales (Johannes Wallensis o Vallensis), con su Compendiloquium de vita et dictis illustrium philosophorum, de fines del siglo xili, y Walter Burleigh, con su Liber de vita et moribus philosophorum poetarumque veterum, compuesto en la primera mitad del XIV, que seguirían influyendo en la Castilla «prerrenacentista", vertidos a la lengua vulgar; escritores, a su vez, más o menos deudores de Diógenes Laercio, Valerio Máximo y Vicente de Beauvais. El marqués de Santillana, por ejemplo, tenía en su biblioteca (cf. BLÜHER, K. A., ob. cit. en la n. 93; págs. 191, n. 101, y 195, n. 113) otra obra de Juan de Gales, el Breviloquium, traducido al italiano, y la de Walter Burleigh, en castellano; ambos autores le depararon casi todos sus aforismos y citas clásicas para los Proverbios y el Bías contra Fortuna. Es de esperar, pues, que dada la boga de esos escritores, otros inventarios aún no explorados permitan rastrearlos en los fondos de Mss. de las bibliotecas nacionales y extranjeras. Por tanto, la presencia de Juan de Gales, que echa en falta la Profesora BECEIRO, I., (véase la n. 112, pág. 142), podrá ser, acaso, una realidad.

Se menciona asimismo "un "De genologia deorum", anónimo" (pág. 50). Con toda seguridad se trata del De genealogiis deorum gentilium, de Boccaccio, comenzado hacia 1350 y terminado en 1367; obra fundamental en la historia del humanismo y en la de nuestra estimativa frente al paganismo, que también circuló como Genologia: vid. sobre la influencia de Boccaccio como nexo entre la Edad Media y el Renacimiento, en los estudios de Mitología, SEZnEC, J., The Survival of the Pagan Gods. The Mythological Tradition and Its Place in Renaissance Humanism and Art. Engl. Transl. Nueva York 1961, págs. 220-24, 235 y ss.; y CouLTER, C. C., The Genealogy of the Gods, "Vassar Medieval Studies", 1923, págs. 317-41. Para la fortuna de Boccaccio en España, véase FARINELLI, A., ob. cit. en la n. 23, vol. I. Santillana poseía un ejemplar de la Genealogia.

A continuación viene un «"Libro felix de les maravelles del mon", en catalán sin duda", que "debe hacer referencia a la conocida obra de Marco Polo" (pág. 50). Es, en nuestra opinión, el Fèlix o Libre de meravelles, de Ramon Llull; pues, aunque el del mercader veneciano corriera con títulos análogos (entre otros, más tarde, el de Libro de las cosas maravillosas, trad. de Rodrigo Fernández de Santaella, $1 .{ }^{a}$ ed. castellana, Sevilla, L. Polono y J. Cromberger, 1503), ese «Fèlix» nos pone sobre la 
pista del «Doctor lluminado", aparte de la lengua. Según BatLlORI, P. $M$., «no se conoce ningún manuscrito medieval o del Renacimiento que contenga esta obra [el Fèlix] en versión castellana»: cf. LLULL, Ramon, Obras literarias. "Libro de Caballería". "Blanquerna". "Félix". Poesías. Ed. de Batllori, M. y Caldentey, M. Introducción biográfica de S. Galmés, etc., Madrid 1948, pág. 603 (B. A. C., 31). Por entonces, otra leidísima obra, la del ficticio Jean de Mandeville, titulada igualmente Libro de las maravillas del mundo (ca. 1350), era ya conocida en aragonés gracias a Juan I, aunque en castellano se documenta solamente a partir de 1515 . Creemos que tampoco es ésta la del inventario. Cf. la ed. facsímil sobre la de Valencia, de 1524, por Martínez Ferrando, J. E., 2 vols., Madrid 1958-60.

Acto seguido aparecen «dos ejemplares del ciclo de la «Historia Troyana» de Guido de Colonna, que el mismo conde mandó traducir» (pág. 50). Estaba ya vertida al castellano, desde 1350, la Historia Troyana de Guido delle Colonne (ca. 1287): es la de Alfonso XI, completa, que salió de la Real Cámara en ese año y se conserva en El Escorial (Sign. h-I6); habiéndose utilizado para la traducción gallego-castellana, de la Biblioteca Menéndez y Pelayo, de Santander, y para la gallega, hoy en la Biblioteca Nacional. Perteneció también a Isabel «la Católica». El precioso códice, ilustrado con bellas miniaturas, ha sido nuevamente estudiado y puesto al alcance del gran público, en sus miniaturas, por GARCía MoRENCOS, P., Crónica Troyana, Madrid, Patrimonio Nacional, 1976. Vid., además, García Solalinde, A., "Las versiones españolas del Roman de Troie», Revista de Filología Española, III (1916), 124 y sgs., y REY, A., Ensayo de una bibliografia de las leyendas troyanas en la literatura española, Bloomington, Ind., 1942.

Volviendo a Ramon Llull, una frase puede resultar equívoca: se dice (pág. 50) que en el inventario figuran dos ejemplares «del «Árbol de la Ciencia», libro de lógica en latín». ¿Debemos leer, quizá, «y un libro de lógica en latín"? Porque el Arbre de sciència luliano era, no un tratado de lógica, sino una enciclopedia compuesta en 1295, cuando sus facultades intelectuales decaían a causa de una «melancolía ansiosa», "cuyas causas morales - piensa GaLmÉs, S., ob. cit., supra, pág. 22- radicarían, a buen seguro, en la gran depresión psíquica que experimentaba desde antiguo, agravada todavía por algún acontecimiento de alta trascendencia subjetiva; por ejemplo, la disolución de su escuela de Miramar, que sospechamos debió de sobrevenir entonces". Ramon Llull tradujo del árabe al catalán, y en verso, la llamada Lógica de Algazel (Lógica d'Algatzel), hacia 1275, y en 1303 dio a la luz su Lógica nova. Entre los incunables lulianos registrados por HAEBLER, K., (véase ob. cit., en la $\mathrm{n}$. 
69, Nos 378-386) están el Arbor scientiae (Barcelona, Pere Posa, 1482) y la Logica abbreviata (Barcelona, Pere Posa, ca. 1489), lo que demuestra su difusión antes y después de la imprenta.

¿Por qué el "Arte breve" tiene que ser necesariamente, el "Arte breve de trovar», de Villena? (cf. pág. 51). Recuérdese que «el arte» por excelencia, desde la Grecia clásica hasta bien entrado el Renacimiento, designa el conocimiento y la práctica médicos: «las dos nociones básicas del saber médico antiguo - dice el Dr. Laín Entralgo, P., Historia de la Medicina, Barcelona 1982, pág. 182-, natura y ars, fueron penetrando «en las casi virginales cabezas de los pensadores y los médicos de Occidente». La expresión, "Arte breve», evoca el Ars parva de Galeno. Pero es que, además, la obrita de Enrique de Villena - que se salvó de una pérdida total gracias a un extracto del siglo XVI- titúlase desde su composición Arte de trovar, simplemente (cf. AMADOR DE LOS Ríos J., Vida del Marqués de Santillana, cit. en la n. 80, págs. 114-115, n. 110), aunque también se la conoció como Gaya ciencia *.

Regístrase en el parrafo siguiente "un «Proprietatibus rerum"» (sic): seguramente el De proprietatibus rerum, tan difundido, del franciscano Bartholomaeus Anglicus, quien escribió esa enciclopedia entre 1225 y 1250. En 1286, del exemplar o texto modelo se hicieron en París 102 peciae o quaderni para los estudiantes, lo que prueba su aceptación en los medios universitarios y su éxito general hasta el siglo xvi: cf., acerca de París, THORNDIKE, L., University Records and Life in the Middle Ages, Nueva York 1949, pág. 113. Bartolomé Ánglico es uno de los autores "científicos» en la biblioteca de Isabel «la Católica» (véase la n. 69).

Las "varias obras de agricultura a las que, a veces, se denomina "caldea"» (pág. 51), pudieran ser las de lbn Wāfid (Abenguefit) o lbn Bașșāl (cf. Millás Vallicrosa, J. M. ${ }^{a}$, ob. cit. en la n. 125, págs. 184-85, y Nuevos estudios sobre historia de la ciencia española, Barcelona 1960, págs. 117-29). En cuanto al "More», si fuese, como sospechan los Profesores Ladero y Quintanilla, el Moré něvukim o Guía de los perplejos, de Maimónides - traducida al castellano, entre 1419 y 1432, por Pedro de Toledo: véase Ms. KK-9, de la Biblioteca Nacional de Madrid, hecha sobre la versión hebrea de al-Harizí-, su presencia en esta biblioteca denotaría, con la de los árabes, un gran interés del $\mid 1$ y III conde de

* No se excluye, obviamente, que el «Arte breve" pueda ser también un texto gramatical, $u$ otro en el sentido de las «artes liberales" (Cf. IsIDono, S., Etym., I, i, 1-10). 
Benavente por los temas semíticos. El marqués de Santillana también la poseía: cf. ScHIFF, M., La bibliothèque..., págs. 425-444.

Por último, figura un «De morbo pestilencie» junto a unas «Recebtas de Galieno», "traducidas al castellano por un judío» (pág. 51). En la colección de Juan de Segovia donada a la Universidad de Salamanca, en 1457, encontramos un Tractatus de pestilencia, de Arnau de Vilanova: véase GonZÁlez, J., ob. cit. en la n. 132 , pág. $178,{ }^{\circ}{ }^{\circ} 81$ de la escritura de donación. Hubo varios tratados con ese título u otro afín. Pero, habida cuenta de la relativa familiaridad que el inventario delata con determinados autores judíos y árabes, podría aventurarse, en el caso del «De morbo pestilencie", la posibilidad de que fuese algún escrito sobre la peste de cualquiera de los acreditados médicos granadinos del siglo XIV, ya al-Saqūrī, ya Ibn Jātima o Ibn al-Jațiib, en alguna traducción desconocida. Claro está que, aquí, nos movemos en el terreno de la hipótesis: tienen la palabra los expertos.

III. La biblioteca del III duque de Medina Sidonia, D. Juan de Guzmán (1507, Arch. de la Real Chancillería de Granada, según el inventario hallado por Bernard Vincent, documento del cual hay textos en el archivo ducal), merece también atención: sus casi 230 volúmenes revelan múltiples inquietudes, a tono con la época. «La variedad temática y de calidades -afirman los Profesores Ladero y Quintanilla - es también grande, y muestra una mezcla de intereses tradicionales y nuevas corrientes de cultura que penetrarían con mayor facilidad, sin duda, en la corte de aquel noble..." (pág. 48). Examinaremos algunas de las 208 partidas (ct. págs. 56-59).

Entre las "obras de religión, moral y piedad» están las más leídas entonces: por ejemplo, dos "Lucero de la vida cristiana» (núms. 32 y 174). Si bien no se menciona, su autor es Pedro Jiménez de Prexano o Préxamo (m. 1495), discípulo de "el Tostado" y que aparece igualmente entre los libros de Isabel «la Católica»; obra luego expurgada y muy frecuente antes de 1500: cf. HAEBLER, K., ob. cit. en la n. 69, Nos. 71218 , con las ediciones de 1493 a 1499, lo que prueba su difusión; véase también la 2. ${ }^{a}$ parte de la Bibliografía ibérica del siglo XV, Nos. 712-17(8), con las impresiones de 1486 a 1496. Otro volumen, el «Espejo de(la) vida humana» (núm. 152), corresponde a Rodrigo Sánchez de Arévalo: cf. HAEBLER, 2. ${ }^{a}$ parte, Nos. 578-79: el 579, bajo el nombre de RoDRIGo DE ZAMORA, es el de Zaragoza, Pablo Hurus, 1491. Isabel I poseía un 
ejemplar de la ed. romana de 1468 , con las armas reales en la portada (cf. Sánchez Cantón, ob. cit. en la n. 60.

Figuran a continuación 11 obras de teología y filosofía. Muy probablemente, los dos ejemplares del «De natura angelica» y el "De suma (sic) angelica" (núms. 12 y 55) sean de Santo Tomás (Summa Theol., Prima Pars, "De Deo creante et gubernante», q. 50-64 y 106-14). Pero el tratado de fray Francesc Eiximenis, OFM, sobre la materia, Libre dels àngels, fue impreso con el titulo Libro de los Santos Ángeles (Burgos, Fadrique de Basilea, 1490: para este autor, véase HAEBLER, ob. cit., Nos. 700-11), y también gozó de especial favor. El Marqués de Santillana poseyó una trad. castellana de Eiximenis: la Natura angélica (cf.ScHIFF, M., ob. cit. en la n. 90, Núm. LXVIII).

Se advierte que el autor del Decamerón está bien representado (Núms. 25, 45, 59, 119, 127 y 138): "Bocaccio con seis, nada menos: hay tres ejemplares del "Fiametta" - dicen los Profesores Ladero y Quintanilla-, uno de sus "novelas" y otro del tratado sobre mujeres ilustres" (pág. 52). Boccaccio se había impuesto no sólo por sus «novelle», las del Decamerone, sino también por la Fiammetta y los tratados latinos, aparte del De genealogiis deorum gentilium: De casibus virorum illustrium y De claris mulieribus. En cuanto al Ninfale d'Ameto, la Amorosa Visione, la Elegia di Madonna Fiammetta y el delicioso Ninfale Fiesolano, eran a su vez objeto de lectura entusiasta, cuyos frutos se darían, con la de Petrarca, en el Alto Renacimiento. Vid. FARINELLi, A., ob. cit. en la n. 23, vol. I, y, en general: Boccaccio in Europe. Proceedings of the Boccaccio Conference (Lovaina, Diciembre 1975), ed. by Tournoy, G. Lovaina, 1975.

El «inevitable "Regimiento de príncipes"» (pág. 52, véase núm. 65), puede ser muy bien el tan extendido de Egidio Romano, De regimine principum (ca. 1285), para la educación política del futuro Felipe IV «el Bello"; con o sin la Glosa castellana de su traductor, Juan García de Castrojeriz, a mediados del siglo XIV y que suele acompañarle. Pero no olvidemos el tratado, de igual título (asimismo conocido como De regno), comenzado por Santo Tomás y terminado por Ptolomeo de Lucca. Y en tierras castellanas, metrificado, el breve Regimiento de príncipes de Gómez Manrique, dirigido a los Reyes Católicos y compuesto antes de 1478. Para Egidio Romano o Colonna, v. los Nos. 154-57 de HAebler, ob. cit. en la n. 69 , quien incluye también el de Gómez Manrique en el núm. 391.

Se mencionan luego, entre las obras «científicas», una «Suma de aresmética» y un libro de «Guarismo y cómputo» (pág. 52, véase núms. 28 y 137). La primera despierta gran curiosidad, porque, o bien existió 
una traducción castellana de la Summa de Arithmetica (1494), por Luca Pacioli, o en la biblioteca el duque la tenía en italiano, dándonos el amanuense o el escribano, sobre la marcha, su versión del título en castellano (lo que debió de ocurrir más de una vez). ¿O nos encontramos con la Summa de la Arismética (1482), de Sant Climent, primer libro impreso en España sobre esa materia?: Cf. BOHIGAS, P., ob. cit. en la n. 17, pág. 91. En todo caso, hacia 1507 se había implantado ya en el mundo comercial la contabilidad por partida doble (el «método veneciano» lo sigue Luca Pacioli, como él mismo confiesa), y ambas obras - especialmente la italiana - eran el vademecum de mercaderes y banqueros. Respecto al "Guarismo y cómputo", acaso esté relacionado con el de computis et scripturis (36 capítulos) incluido, para la teneduría de libros por partida doble, en la Summa de Luca Pacioli. Cf. YAMEY, B. S., "Scientific Bookkeeping and the Rise of Capitalism», Economic History Review, ser. 2. I (1949), 99 y sgs.

Además del «Bocavolisti» (sic), que figura en la partida $n .{ }^{\circ} 5$, es decir, el Universal Vocabulario en latín et en romançe, de Alfonso de Palencia (Sevilla 1490), que poseyó su destinataria, la Reina Isabel, y registrado también (Nos. 42 y 43) como «Vocalista", se menciona "otro libro enquadernado pequeño que dize la perfecion del triunfo" ( . $^{\circ} 160$ ); con toda seguridad, el tratado de Palencia sobre la Perfeçion del Triunfo militar (Sevilla, ca. 1490), ed. por Fabié, A. M. ${ }^{a}$ Dos tratados de Alfonso de Palencia. Con un estudio biográfico y un glosario. Madrid, 1886 (Colec. «Libros de antaño», V), y por Penna, M. (véase la n. 41, págs. CXXXVI-CLXIV y 345-92).

En lo que concierne al $n .^{\circ} 144$, "otro libro, de los pasados de la ley vieja», es difícil pronunciarse. Según los Profesores Ladero y Quintanilla, «ha de ser algún texto sagrado judío, seguramente» (pág. 51). Como dudamos de que se aluda, con tan vago título, a la Torá o, v. gr., a una obra talmúdica, nos atrevemos a pensar en un texto o corpus legal, cristiano, ya de la época alfonsí, yá muy anterior. ¿El Liber iudiciorum o Fuero Juzgo? ¿El Fuero Viejo de Castilla? ¿El Libro de los Fueros de Castilla? ¿El Fuero Real?... Para el escribano de turno, esos textos, u otros, debían de ser la «Ley Vieja».

IV. El estudio que la Profesora C. Quintanilla Raso consagra a la bien provista biblioteca del I marqués de Priego, D. Pedro Fernández de Córdoba (véase la n. 126), ratifica el profundo conocimiento que su autora tiene de los grandes linajes andaluces y su acabada maestría en el 
aprovechamiento de las fuentes primarias. Nos ofrece, así, un perfil muy interesante de aquel personaje $y$, sobre todo, nos brinda un inventario por demás nutrido y sugestivo (1518, agosto: Arch. Ducal de Medinaceli, sec. Priego, leg. 7, doc. 1), que pone de manifiesto los avances humanísticos promovidos en el Occidente con las nuevas auras renacentistas. El nivel de la cultura aristocrática sube en calidad y riqueza de contenidos, a juzgar por las bibliotecas que, desde fines del siglo XV y durante el primer tercio del $\mathrm{XV}$, se formaron en toda Europa $\mathrm{y}$, concretamente, en España. Aunque las notas de la Profesora Quintanilla, a un total de 127 partidas sobre las 268 del inventario, constituyen un instrumento de trabajo para la identificación segura o probable, asi como para un breve comentario sobre autores y obras, también en este caso nos permitiremos algunas observaciones que, a su vez, naturalmente, pueden ser objetables, dados los escasos elementos de juicio disponibles en ciertas partidas. Como en las anteriores puntualizaciones, la extensión justifícase por el número de quaestiones disputatae, cuando no de errores y lagunas que exigen atención crítica.

Se indican los números de las partidas, los autores, las obras y, según los casos, las notas de la Profesora Quintanilla.

1. «Una regla de San Benito». Anterior en diez años a la ed. que se cita (Montserrat, Juan Luschner, 1499), es la princeps (Venecia 1489). Cf. San Benito. Su vida y su Regla. Edición e introducciones del P. Colombás, G. M. Versiones del P. Sansegundo, L. M. Comentarios y notas del P. Cunill, O. M. Madrid 1954, pág. 259 (B. A.C., 115).

9. Valerio Máximo. «En esta misma biblioteca — se anota- existian otras obras suyas (ver las partidas núms. 84, 158, 237, 239 y 266, ésta última impresa, según se especifica»... «En ningún caso se nos dice el título; es posible que se tratara de Hechos $y$ dichos memorables dedicados al emperador Tiberio..." (pag. 370). Implícitamente se da a entender que de tal autor figuran en la lista «otras obras», pero desde la Antigüedad únicamente se conocen sus Factorum ac dictorum memorabilium libri $I X$, de tan favorable acogida hasta el Renacimiento. Hay de Val. Max. dos epítomes tardíos: el de Julio Paris (siglo IV?), con el De praenominibus o breviario de los nombres romanos atribuidos a $\mathrm{C}$. Ticio Probo $\mathrm{e}$ indebidamente incorporado a los Dichos $y$ hechos como su libro $\mathrm{X}, \mathrm{y}$ el de Januario Nepociano (siglo $v$ ?). Fue traducida al castellano por Ugo de Uríes (Zaragoza, Pablo Hurus, 1495): cf. HaEBleR, K., ob. cit. en la $n$. 69, n. ${ }^{\circ}$ 663. Acaso el marqués de Priego, en sus contactos con Italia - a través de un lejano pariente, el impresor valenciano Alfonso Fernández de Córdoba, o de diversos agentes- poseyera la bella edición aldina (Venecia, 1502), de bolsillo, reimpresa en 1514. Vid., sobre Valerio Má- 
ximo, Rénouard, A. A., Annales de l'imprimerie des Aldes, ou histoire des trois Manuces et de leurs éditions, 3 vols., Paris, ${ }^{3} 1834$; cf., para la ed. de 1502, el vol. I, págs. 86-87. Más referencias sobre los Aldos, en Febvre, L. - Martín, H. J., ob. cit., en la n. 3, págs. 497 y 504-5.

13. "Oraçiones del Tulio, con otro libro que se llama ystoria rerum del papa Pyo...». "Es posible»-leemos, respecto a Eneas Silvio Piccolomini, Pío II - «que se tratase de una de sus obras más difundidas: Asiae Europaeque elegantissime descriptio... (pág. 371). Parece ser, claramente, la Historia rerum ubique gestarum, "grande opera storico-geografica che va sotto il nome di Cosmographia", según PAPARELLI, G., Enea Silvio Piccolomini (Pio II), Bari 1950, pág. 51. Cf. Opera omnia (Basilea 1571), págs. 281-471. El Almirante Colón apostilló su ejemplar: véase Cristóbal Colón, Textos y documentos completos. Prólogo y notas de Varela, C. Madrid 1982. págs. LI-LII (Alianza Editorial, AU 320).

20. "Laurencio Vala...". No consta la obra, posiblemente el De voluptate, De vero bono, De libero arbitrio, u otra de Lorenzo Valla. La autora propone también «De elegantia linguae latinae lib. VI, de la que se hicieron numerosas ediciones en los siglos $x V$ y $X V i$, algunas españolas» (pág. 371). Quizás. Pero el título correcto del famoso tratado, verdadera summa del humanismo formal, es Elegantiarum linguae latinae libri VI (1444).

31. «Las obras de las antiguedades despaña de Alonso de Palencia...». En la nota correspondiente se las confunde con los Gesta Hispaniensia ex annalibus suorum diebus colligentis, o Décadas (pág. 373). El Profesor TATE, R. B., que prepara una edición crítica de las Décadas, ha señalado también este error: cf. Alonso de Palencia and his 'Antigüedades de España», pág. 196, n. 4. (Al no figurar, en la xerocopia de este artículo facilitada amablemente por D. Eloy Benito Ruano, ninguna indicación sobre la publicación en que apareció, nos es imposible precisar la referencia bibliográfica).

36. «Un bocabulario de Alonso de Palencia...". "Conviene recordar - se dice- que [Palencia] sustituyó a [Juan de] Mena como "secretario de latín" al servicio de Juan Il» (pág. 373). Fue el 6 de septiembre de 1456: véase, p. ej., PAZ Y MELIA, A., en su trad. de la Crónica de Enrique IV [o Décadas], vol. I, Madrid 1973, pág. X, núm. 3 (B. A. E., 257). Fuente: Arch. de Simancas, Quitaciones de Corte, legajo 21.

40. "Solino de las cosas memoriales del mundo...". "Traducida al castellano - se advierte - con el título de Cosas maravillosas de el Mundo por Cristóbal de las Casas, fue impresa en Sevilla en el último tercio del siglo XVI» (pág. 373). Hay, sin embargo, una edición hispalense de 
1523. Fue aún apreciado en el siglo XVi, aunque no tanto como en la Edad Media: véase, p. ej., la versión de GolDING, Arthur, The Excellent and Pleasant Works of Julius Solinus, Polyhistor. Translated by, Londres 1587. Solino era leído, en México, en 1576: véase LEONARD, I. A., Los libros del conquistador, trad. española, México 1953, págs. 173 y 211.

54. «Un Plynio en marca grande...». «Es posible que en esta ocasión - dice la autora- y en el núm. 91 se tratara de alguna obra de Plinio el Viejo, como Naturalis Historia...» (pág. 374). Al igual que en el núm. 9, a propósito de Valerio Máximo, sorprende tal alusión a otros eventuales títulos del erudito romano, ya que su Historia Natural es la única obra sobreviviente de las siete mencionadas por Plinio "el Joven", su sobrino, en Ep., lib. III, 5, donde se enumeran los perdidos escritos acerca de temas militares, históricos, gramaticales y retóricos, además de una biografía, la de Pomponius Secundus, su amigo y preceptor literario.

59. «Tratado de animalias...». Coméntase: «Tal vez es la obra de este título de Avicena» (pág. 375). Ciertamente, "su bibliografía crítica - según Cruz Hernández, M.,- es aún un complicado problema», pues se le atribuyen 242 títulos: véase Historia del pensamiento en el mundo islámico, vol. I: Desde los orígenes hasta el siglo XII, Madrid 1981, pág. 206. Ahora bien, entre las obras de Avicena editadas críticamente o traducidas, la única de tema zoológico es la que lleva por título Risālat a/Tayr o «Tratado de los pájaros».

64. «Las obras del Pontano». A este autor se le presenta como «astrónomo» (pág. 375), cuando, en realidad, Giovanni Pontano fue un poeta, funcionario y humanista al servicio de la Casa de Aragón en Nápoles (m. en 1503), durante los vaivenes político-militares y diplomáticos que conmovieron a Italia. Su poema Urania, su tratado De rebus coelestibus y su diálogo Aegidius muéstranle informadísimo sobre la astrología, pero, ante todo, contempla el universo estética, no científicamente: cf. Russo, L., ed., I classici italiani. Dal Ducento al Quattrocento. Vol. I, Parte 2. , Florencia 1966, pág. 1215-37.

74. «Conpendio teolugia». Tan indefinido título impide, por su propia generalidad, adscribirlo a nadie. Sin embargo, la nota respectiva, categóricamente, nos ilustra sobre la obra y el autor: «Sin duda -leemos-, el Compendium theologicae veritatis de san Alberto Magno" (pág. 375). Pero si consultamos cualquier estudio crítico acerca del eximio maestro y obispo, en busca de tal compendio, nuestras esperanzas se verán defraudadas. Así, p. ej., Garreau, A., San Alberto Magno. Introducción de P. Mandonnet. Trad. espñ., Buenos Aires 1944, págs. 21213: «El Compendium theologicae Veritatis —dice el autor- es probable- 
mente de Hugo Ripelin de Estrasburgo". Grabmann, M., Hist. de la Teología católica... (cit. supra, pág. 38), pág. 93, también se lo atribuye.

82. "Laerçio enquadernado. "Quizás se trataba de la obra Vitae philosophorum de Diógenes Laercio...» (pág. 376), se insinúa. Evidentemente, porque de sus Epigramas sólo nos quedan los que él introdujo en las Vidas, opiniones y sentencias de los filósofos más ilustres.

83. "Ortus sanitatis». La autora, en su nota (pág. 37), aventura: «Tal vez la obra de Maimónides...». Si acudimos, p. ej., a los trabajos reunidos con el título Maimónides y su época, Córdoba 1986 (Conferencias y Exposición en el Palacio de la Merced, dentro de los actos conmemorativos del 850 aniversario del sabio) y repasamos sus obras de medicina traducidas, ninguna responde a ese título (cf. págs. 117-20). La más parecida, y tópica, es el De regimine sanitatis (trad. en el siglo XIII e impresa en Florencia ca. 1480, y en Venecia, 1514). Por el contrario, en la Europa del siglo xv los herbarios con el título de Horti u Hortuli llegan a constituir una literatura médico-botánica de gran interés y de origen monástico al par que greco-árabe: a fines de esa centuria se imprimen y divulgan como obras populares, destinadas a un público lego, pero que desea velar por su salud mediante las plantas. Uno de los más célebres, al tiempo que uno de los mejor editados, es el Hortus Sanitatis de Juan de Cuba, pronto difundido, tanto en latín como en alemán, francés e italiano. Tuvieron mucho éxito el Gart der Gesundheit (Maguncia, Schoeffer, 1485, el Arbolajre (Besançon, 1490), el Herbario de Apuleyo (Roma, 1483), etc. Cf. Castiglioni, A., Histoire de la Médecine, trad. fr., Paris 1931, págs. 298-99 y 334-35. También, Laín ENTRALGo, P., Historia de la Medicina, Barcelona 1982, págs. 231-32, y KLEBS, A. C., Incunabula scientifica et medica, Brujas 1938.

87 y 227. "Josefo de antiguedad" y "Josefo de belo judayco». No se comentan, pero el segundo debe de ser el traducido por Alfonso de Palencia (Sevilla, 1492): cf. HAEBlER, K., ob. cit. en la n. 69 y núm. 344.

102. «Un libro que se llama el oraçional...». Tampoco se identifica: seguramente porque, con dicho título -en apariencia muy común-, no atrae demasiado la atención. Sin embargo, nos inclinamos a creer que se trata del Oracional de Alfonso de Cartagena, quien lo dedicó a su amigo Fernán Pérez de Guzmán, en 1454, correspondiendo a una petición expresa de éste: véase las Generaciones y semblanzas, ed. Domínguez Bordona, citado en la n. 27, págs. 217-21, con la respuesta del obispo de Burgos. Para la valoración del Oracional como obra ascética y exponente, con el Memoriale virtutum (1422), de la sabiduría y piedad de su autor, véase también Dı CAMILLO, O., ob. cit. en la n. 23, págs. 156- 
66, y LOPEz ESTRADA, F., «La retórica en las Generaciones y semblanzas, de F. Pérez de Guzmán», «Rev. Filol. Española», XXX (1946), 310-52.

179-180. «Un contentus mundi...». En la nota se dice: «Podía tratarse de la obra De contemptu mundi, de Erasmo; sin embargo, fue un título muy usado en la Edad Media...» (pág. 378). Tenemos, ciertamente: INOCENCIO III, De contemptu mundi sive de miseria conditionis humanae libri tres (Migne, PL, t. CCXVII, pág. 702); Gerson, Jean, Contemptus mundi (Zaragoza, Pablo Hurus, 1490) y Del menosprecio del mundo (Toledo, Pedro Hagenbach, 1500), en Haebler, Nos. 295 y 297; Cato, De contemptu mundi (sin indicaciones tipográficas, pero en Sevilla, por Men, Ungut y Stanislao Polono, ca. 1495), etc. Cf. la partida núm. 210: «Un librete de pergamino de miseria condiçionis umane...", seguramente el de Inocencio III. Este, a su vez, inspiró el Libro de miseria de omne (siglo Xiv).

184. «Mirabilia Rome». No se añade nota, pero debe de ser el tradicional corpus descriptivo, entre arqueológico-histórico y legendario, de la Roma pagana y cristiana cuya primera redacción —según los historiadores del arte- se atribuye a Benedictus Canonicus, un coetáneo de Arnaldo de Brescia, es decir, a mediados del siglo xir, cuando ya resurgían el interés, la admiración y el orgullo por la Roma clásica. Se sabe de precedentes carolingios, como el Anónimo de Einsiedeln (Suiza, cantón de Schwyz), que contiene una relación de monumentos a dos columnas y en dos o tres folios, pero con la novedad -sobre los anteriores «regionarios» y Noticiae- de que aúna los edificios paganos y cristianos. Muy probablemente disponíase ya de planos o mapas topográficos de la Urbe. Corrían, además, como en el Anónimo de Salerno bajo los Otones, multitud de relatos legendarios sobre Roma; pero la renovatio imperii- en tiempo de Otón III, sobre todo- provoca gran entusiasmo "laico", testimonio del cual es la Graphia aureae urbis Romae, destinada por igual a los doctos y a los fieles sencillos que visitaban la Ciudad Eterna en peregrinación.

Los Mirabilia se convirtieron, así, no sólo en documento semi-oficial de la Curia a fines del siglo XIV, sino que, revisados y ampliados del siglo XIV al XV, tomaron la forma de una guía con sus itinerarios, explicados desde el Vaticano hasta el Trasievere. Petrarca y otros humanistas, viajeros, etc., la utilizaron como «obra de referencia». Cf. la ed. NicHols, F. M., Mirabilia Urbis Romae. The Marvels of Rome. Londres 1889, págs. 1-26 y 35-78. También es informativo, aún, Gregorovius, F., Roma y Atenas en la Edad Media, trad. espñ., México 1982, págs. 70-75 (se recogen aquí tres capítulos de la voluminosa obra, sobre Roma en los 
siglos $\mathrm{X}$, XIII y XVI). Si no estamos equivocados, el marqués de Priego tenía alguna edición de los Mirabilia en su rica y selecta biblioteca.

196. «La estoria betyca...». Tampoco se comenta la partida. En el Cancionero Musical de la Biblioteca Colombina (Ms. 7-I-28), tan importante - con el de Palacio - en la historia de la música española, el italiano Carlo Verardi (ca. 1440-1500) figura con un villancico patriótico que exalta a Fernando «el Católico» por la conquista de Granada. Su autor lo incorporó a su drama latino Expugnatio regni Granatae o Historia Baetica, estrenado en Roma el 21 de abril de 1492, donde era secretario y cubicularius del Papa. ¿Se trata de la misma obra, dando el título traducido, o acaso de una versión castellana? Vid., para Verardi, TORRE Y DEL CERRO, A. DE LA, Los Reyes Católicos y Granada, Madrid 1946, pág. 133, n. 13: remite a BARRAU-DiHIGo, I., «Revue Hispanique», XLVII (1919), 319-82, quien publica la Historia Baetica. Vid. también Stevenson, R. M., Spanish Music in the Age of Columbus, La Haya 1960, y la grabación Music from the Court of Ferdinand and Isabella. The Early Consort, Dir. by D. Munrow (Refer.: S-36926 ANGEL). Para las ediciones españolas, Cf. HAEBLER, K., ob. cit., Nos. 667 y 667(5).

204. “Un cosmografya de Teofastro ...». «La presencia de su Cosmografía - se dice- entre los fondos del marqués de Priego, quizás indica un especial interés de su propietario por esta materia" (pág. 379). Desgraciadamente, no es posible dar por sentado que en los siglos $x V$ y XVI -a pesar de los hallazgos y ediciones, entonces, de Mss. griegosexistiera una Cosmografía u obra análoga de Teofrasto. En nuestro tiempo, ningún filólogo clásico alude para nada a ella; por lo menos, las obras de referencia que el no especialista puede consultar (diccionarios del Mundo Clásico, tratados y manuales de literatura griega, de filosofía y ciencia en la Antigüedad, etc.), no contienen ese título entre los de Teofrasto. $Y$ si examinamos detenidamente el catálogo de sus obras por Diógenes Laercio (Vidas..., V, 4), que enumera hasta 224, con un total, dice, de 230.808 líneas - aunque la fiabilidad de Laercio es, como se sabe, dudosa-, entre ellas falta precisamente una "Cosmografía». Figuran tan sólo De meteoros, De la naturaleza, De Física, De problemas físicos...; todas ellas perdidas, a excepción de los Conocimientos botánicos y Sobre los orígenes de las plantas *, más la tan popular sobre Los caracteres, diversos trataditos (mineralogía, meteorología, fisiología) y fragmentos más o menos extensos de otros. En el siglo vı existía aún su

* Es la también conocida como Historia de las plantas. 
Historia de la Física, pero desde entonces no se habló de ninguna «Cosmografía» entre los rari nantes de la Tardía Antigüedad.

215. «Una parte de las obras de Deonisio...». La nota reza: «En este caso, es posible que se tratase de Dionisio el Areopagita, autor presente también en la biblioteca del marqués de Cenete» (pág. 379). El neoplatonismo se había extendido, por supuesto, y el Pseudo-Dionisio conservaba intacto su prestigio medieval, pero cabe asimismo otra posibilidad: Dionisio de Ryckel, «el Cartujano" (m. 1471), tan leído en el otoño medieval y del que nos quedan bastantes incunables: cf., para España, HAEBLER, ob. cit. en la n. 69, p. ej., su De quatuor novissimis s. Cordial, en la trad. de Gonzalo García de Santa María (Zaragoza, Pablo Hurus, 1491 y 1494; más - sin nombre de impresor- las de Valencia, 1495, y Zaragoza, 1499). Tomista y, en mística, seguidor del PseudoDionisio, el Cartujano, dice SaInz Rodríguez, P., «es uno de los autores que más influyeron en nuestro misticismo del siglo de oro, y muy especialmente sobre Santa Teresa" (véase su Introducción a la historia de la literatura mística en España, Madrid 1986, pág. 116, y cap. V). Es más comprensible, por tanto, su presencia que la del Areopagita. No debe excluirse, empero, la eventualidad de que el marqués de Priego poseyera un ejemplar de la edición del Ps. Dionisio aparecida en Estrasburgo (1502-3), y que se difundió tanto en la España del siglo XVI: vid. Obras completas del Pseudo-Dionisio Areopagita, ed. de T. H. Martin, Madrid, 1990, nágs. 99-100 (B.A.C., 511).

247. «Un libro de Aben Ruis...». Se comenta: « ¿Aben Ruis? Quizás se trata de Averroes...» (pág. 381). Efectivamente. Para dar un ejemplo expresivo, Fernán Pérez de Guzmán, en sus Loores de los claros varones de España, dice:

e de Avén Ruiz, pagano,

nos plaze su Comentar [de Aristóteles]...

CAstro, A., cita estos versos y remite a Juan de Mena y Francisco Delicado, para ilustrar el "Aben Ruiz» también en ellos (véase La realidad histórica de España, México 1954, págs. 578-79). 